\title{
Feedback between deformation and magmatism in the Lloyds River Fault Zone: An example of episodic fault reactivation in an accretionary setting, Newfoundland Appalachians
}

\author{
C. Johan Lissenberg ${ }^{1,2}$ and Cees R. van Staal ${ }^{1,3}$ \\ Received 4 January 2005; revised 23 March 2006; accepted 19 April 2006; published 8 July 2006.
}

[1] The Lloyds River Fault Zone is a $10-15 \mathrm{~km}$ wide amphibolite-grade shear zone that formed during the Ordovician Taconic Orogeny. It separates ophiolites and arc-back-arc complexes formed in Iapetus from a periLaurentian microcontinent (Dashwoods microcontinent). The Lloyds River Fault Zone comprises three high-strain zones, dominantly composed of mylonitic amphibolites, separated by less deformed plutonic rocks. Structural, age and metamorphic data suggest the Lloyds River Fault Zone accommodated sinistral-oblique underthrusting of ophiolites underneath the Dashwoods microcontinent prior to $471 \pm 5 \mathrm{Ma}$ at $800^{\circ} \mathrm{C}$ and $6 \mathrm{kbar}$. Plutonic rocks within the Lloyds River Fault Zone comprise two suites dated at $464 \pm 2$ plus $462 \pm 2$ and $459 \pm 3 \mathrm{Ma}$, respectively. The younger age of the plutons with respect to some of the amphibolites, evidence for magmatic deformation, and the elongate nature of the plutons parallel to the Lloyds River Fault Zone suggest they were emplaced within the fault zone during deformation. Both intrusive episodes triggered renewed deformation at high temperatures $\left(770-750^{\circ} \mathrm{C}\right)$, illustrating the positive feedback between deformation and magmatism. Offshoots of the plutons intruded undeformed ophiolitic gabbros outside the Lloyds River Fault Zone. Deformation localized within the intrusive sheets, coeval with static contact metamorphism of the host gabbros, leading to the development of new, small-scale shear zones. This illustrates that channeling of plutons into shear zones and nucleation of shear zones in melt-rich zones may occur simultaneously within the same fault system. Citation: Lissenberg, C. J., and C. R. van Staal (2006), Feedback between deformation and magmatism in the Lloyds River Fault Zone: An example of episodic fault reactivation in an accretionary setting, Newfoundland Appalachians, Tectonics, 25, TC4004, doi:10.1029/2005TC001789.

\footnotetext{
${ }^{1}$ Department of Earth Sciences, University of Ottawa, and OttawaCarleton Geoscience Centre, Ottawa, Ontario, Canada.

${ }^{2}$ Now at Woods Hole Oceanographic Institution, Woods Hole, Massachusetts, USA.

${ }^{3}$ Also at Geological Survey of Canada, Natural Resources Canada, Ottawa, Ontario, Canada.

Copyright 2006 by the American Geophysical Union. 0278-7407/06/2005TC001789\$12.00
}

\section{Introduction}

[2] Magma extraction, transfer and emplacement in orogenic belts are often associated with large-scale shear zones, resulting in an intimate interplay between deformation and magmatism. However, the genetic relationships between deformation and pluton emplacement remain controversial; was deformation localized in melt-rich zones as a consequence of the rheological contrasts between the pluton and the host rock [e.g., Hollister and Crawford, 1986; Vauchez et al., 1997; Brown and Solar, 1998], or were magmas emplaced along active shear zones, as these provide efficient pathways for pluton ascent and emplacement [e.g., McCaffrey, 1992; Moyen et al., 2003; Rosenberg, 2004]? This causality persists because criteria to unequivocally distinguish between the two end-members are sparse, the positive feedback between deformation and magmatism may make reconstruction of the original relationships difficult.

[3] The Lloyds River Fault Zone is a fundamental boundary in the Newfoundland Appalachians that formed during the Ordovician Taconic orogeny. It forms part of an extensive fault system that extends for at least $200 \mathrm{~km}$ and accommodated convergence between suprasubduction zone intraoceanic rocks formed above a west dipping subduction zone in Iapetus and the peri-Laurentian Dashwoods microcontinent situated to the west [Waldron and van Staal, 2001; Lissenberg and van Staal, 2002; Lissenberg et al., 2005a, 2005b] (Figure 1). Specifically, it marked the site of subduction of an infant arc terrane preserved as the Annieopsquotch ophiolite belt, in analogous fashion to subduction of the fore arc in Taiwan [e.g., Chemenda et al., 2001]. The Lloyds River Fault Zone is marked by several amphibolite-grade shear zones that contain two suites of syntectonic plutonic rocks [Lissenberg and van Staal, 2002]. An extensive mapping program [Lissenberg et al., 2005c; van Staal et al., 2005a, 2005b, 2005c], in conjunction with high-precision $\mathrm{U} / \mathrm{Pb}$ and ${ }^{40} \mathrm{Ar} /{ }^{39} \mathrm{Ar}$ geochronological data [e.g., Dunning et al., 1989; Whalen et al., 1997; Lissenberg et al., 2005a], has provided a well-defined geological framework for southwest to central Newfoundland. The Lloyds River Fault Zone therefore presents an excellent opportunity to study the feedback mechanisms between shear zones and syntectonic magmatism.

[4] This paper describes the structural characteristics of the Lloyds River Fault Zone, its relationship to spatially associated plutonic rocks, and the implications of geothermobarometry of both Lloyds River Fault Zone tectonites and plutonic rocks. We integrate these with $\mathrm{U} / \mathrm{Pb}$ and 
${ }^{40} \mathrm{Ar} /{ }^{39} \mathrm{Ar}$ geochronological data presented elsewhere [Lissenberg et al., 2005a], and derive a model for the evolution of the Lloyds River Fault Zone. We will conclude that the Lloyds River Fault Zone channeled magma transport and facilitated pluton emplacement, but pluton emplacement in turn played an active role in strain localization.

\section{Geological Framework}

[5] The Appalachian mountain chain formed as a result of the Cambrian-Silurian closure of the Iapetus Ocean (including seaways and marginal basins), and resulted in the juxtaposition of Laurentia with various peri-Gondwanan continental blocks. In Newfoundland, the Appalachians have been subdivided into numerous zones with distinct tectonostratigraphic characteristics [Williams, 1979] (Figure 1). The Dunnage Zone preserves the remnants of rock assemblages formed within the oceanic realm of Iapetus, and is subdivided into the Exploits subzone, which comprises rocks of peri-Gondwanan affinity, and the Notre Dame subzone, which contains peri-Laurentian rocks [Williams et al., 1988] (Figure 1). The two subzones are separated by the fundamental suture zone of the Newfoundland Appalachians, the Red Indian Line. The Notre Dame Subzone is dominated by the Late Cambrian to Silurian continental Notre Dame Arc (488-429 Ma [Whalen et al., 1987; Dubé et al., 1996; Whalen et al., 1997]), obducted ophiolites of the Lushs Bight and Baie Verte oceanic tracts [Swinden et al., 1997], and arc-back-arc complexes and ophiolites of the Annieopsquotch Accretionary Tract [van Staal et al., 1998; Lissenberg et al., 2005a; Zagorevski et al., 2006]. Tectonic emplacement of Lushs Bight and correlative ophiolitic rocks occurred in the Late Cambrian [Swinden et al., 1997], immediately proceeding metamorphism and early Tremadoc magmatism associated with the Notre Dame Arc. However, the Humber zone, which represents the Laurentian Grenville basement and its passive margin cover sequence, records the persistence of passive margin sedimentation until circa $475 \mathrm{Ma}$ [Waldron and van Staal, 2001]. This disparity between early orogenesis and continuous passive margin development, combined with paleomagnetic arguments [Cawood et al., 2001] suggests the Notre Dame Arc was built on a microcontinent, referred to as the Dashwoods microcontinent, which was separated from the Laurentian margin by an oceanic basin termed the Humber Seaway [Waldron and van Staal, 2001]. Closure of the Humber Seaway by east directed subduction underneath the Dashwoods microcontinent in the early Ordovician initiated the Taconic collision between the Dashwoods microcontinent and the Laurentian margin by at least 475 Ma [Waldron and van Staal, 2001].

[6] The Dashwoods-Laurentia collision initiated west directed subduction outboard of the composite margin (Laurentian margin + Dashwoods microcontinent [Lissenberg et $a l ., 2005 \mathrm{~b}]$ ), leading to the formation of the most outboard unit of the Notre Dame Subzone, the Annieopsquotch Accretionary Tract. This unit comprises a series of east vergent thrust slices dominantly composed of ophiolites and arc-back-arc complexes formed between 480 and 464 Ma [van Staal et al., 1998; Lissenberg et al., 2005a; Zagorevski et al., 2006] (Figure 1), that were accreted to the composite Laurentian margin between 471 and $450 \mathrm{Ma}$ [Lissenberg et al., 2005a, 2005b; Zagorevski et al., 2006]. The largest, structurally highest unit of the Annieopsquotch Accretionary Tract is the Annieopsquotch ophiolite belt, a $\sim 200 \mathrm{~km}$ long, narrow belt that comprises three nearly complete ophiolites; the King George IV, Annieopsquotch and Star Lake ophiolites (Figure 1a). It originated at 481$478 \mathrm{Ma}$ [Dunning and Krogh, 1985] during initiation of west directed subduction in Iapetus following the accretion of the Dashwoods microcontinent to Laurentia [Lissenberg et al., 2005b]. The Annieopsquotch Accretionary Tract is bounded to the southeast by the Red Indian Line, which juxtaposes it with peri-Gondwanan arc-back-arc sequences, and to the northwest by the Lloyds River Fault Zone, which separates it from the Notre Dame Arc and its Dashwoods continental basement. The Lloyds River Fault Zone thus constitutes a fundamental tectonic boundary that accommodated the transfer of intraoceanic complexes to the composite Laurentian margin.

[7] Plutonic rocks within the Lloyds River Fault Zone comprise two suites, defined as the Pierre's Pond suite and Portage Lake monzogabbro [Whalen et al., 1997; Lissenberg et al., 2005a] (Figure 1). They are coeval with the second, voluminous magmatic pulse of the Notre Dame Arc (468-456 Ma [Dunning et al., 1989; Whalen et al., 1997]) and are dominated by arc-like compositions, suggesting an overall consanguineous relationship [Lissenberg et al., 2005a]. This magmatic episode generated large volumes of both arc and non-arc plutons throughout the Notre Dame subzone in a short time span, and occurred circa $10 \mathrm{Ma}$ after the collision between the Dashwoods microcontinent and Laurentia. Consequently, this magmatism has been attributed to slab break off of the oceanic portion

Figure 1. (a) Simplified geological map of the Annieopsquotch Accretionary Tract (AAT), modified from Lissenberg et al. [2005c] and van Staal et al. [2005a, 2005b, 2005c], showing the Lloyds River Fault Zone and the locations of samples used for geothermobarometry (numbers correspond to Tables 1-3). Inset shows location of the study area, Hungry Mountain Thrust (HMT), Little Grand Lake Fault (LGLF), and Lithoprobe seismic reflection profiles, as well as the extent of the Annieopsquotch Accretionary Tract. Ages discussed in this paper are marked by black $(\mathrm{U} / \mathrm{Pb})$ and white $(\mathrm{Ar} / \mathrm{Ar})$ stars [from Lissenberg et al., 2005a]. (b) Cross section through the Annieopsquotch Accretionary Tract (no vertical exaggeration). An, Annieopsquotch ophiolite; CSZ, central shear zone; ES, Exploits subzone; KGIV, King George IV ophiolite; L-B-R, Lloyds River Complex+Buchans Group+Red Indian Lake Group; NDA, Notre Dame Arc; NWSZ, northwestern shear zone; OBSZ, Otter Brook shear zone; PLM, Portage Lake monzogabbro; RIL, Red Indian Line; SESZ, southeastern shear zone; SL, Star Lake ophiolite. 


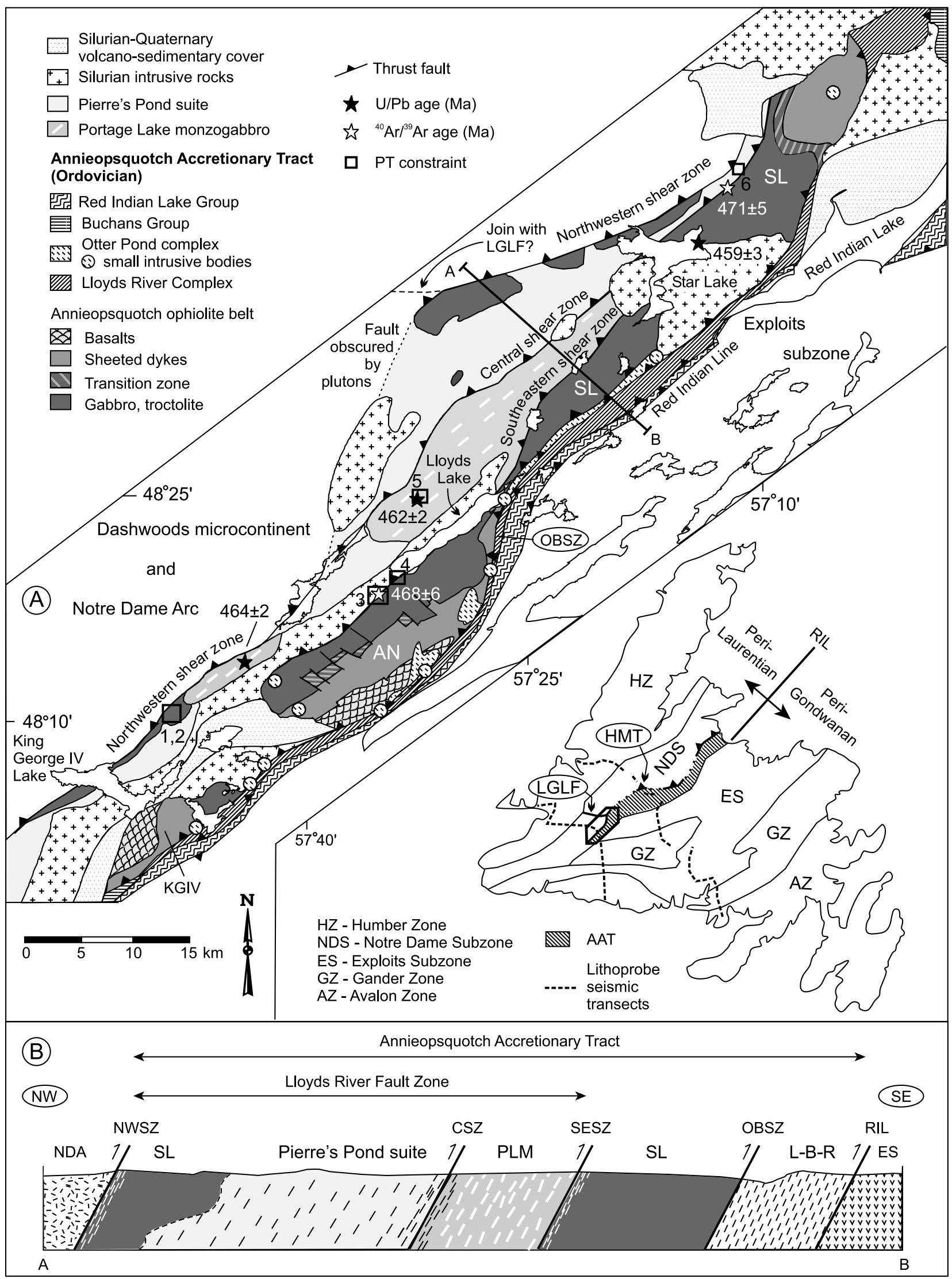

Figure 1 


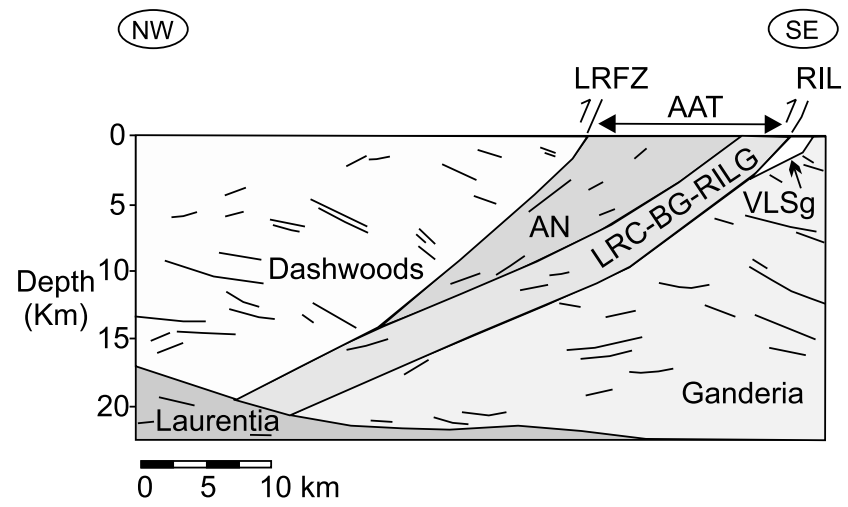

Figure 2. Schematic results of the Burgeo Lithoprobe seismic transect through southwestern Newfoundland, modified from van der Velden et al. [2004]. Lines mark orientations of major reflectors. See Figure 1 for location. AAT, Annieopsquotch Accretionary Tract; AN, Annieopsquotch ophiolite; LRC-BG-RILG, Lloyds River Complex, Buchans Group and Red Indian Lake Group; LRFZ, Lloyds River Fault Zone; RIL, Red Indian Line; VLSg, Victoria Lake Supergroup.

of the Laurentian plate following closure of the Humber seaway [van Staal et al., 2003; Whalen et al., 2006].

\section{Lloyds River Fault Zone}

\subsection{Field Description}

[8] The Lloyds River Fault Zone separates large ophiolite massifs of the Annieopsquotch ophiolite belt from the Dashwoods microcontinent and its Notre Dame Arc suprastructure to the northwest. It is dominated by intrusive rocks of the Pierre's Pond suite and Portage Lake monzogabbro but contains significant amounts of amphibolites and gabbros, which are relics of the Annieopsquotch ophiolite belt [Lissenberg et al., 2005b]. The Lloyds River Fault Zone is $10-15 \mathrm{~km}$ wide north of Lloyds Lake, but narrows considerably to the northeast and southwest, where the intrusive rocks are less abundant (Figure 1). Although deformation is distributed over the entire width of the zone, three major high-strain zones have been recognized, herein referred to as the southeastern, central and northwestern shear zones (SESZ, CSZ, and NWSZ, respectively; Figure 1). These shear zones are characterized by highly deformed and metamorphosed rocks, and are separated by relatively low-strain domains dominated by variably deformed and metamorphosed plutonic rocks of the Pierre's Pond suite and Portage Lake monzogabbro. On the Lithoprobe seismic reflection profile, the Lloyds River Fault Zone appears as a moderately northwest dipping reflector that can be traced to $15 \mathrm{~km}$ depth [van der Velden et al., 2004] (Figure 2). The seismic data suggest that the Lloyds River Fault Zone is cut off at depth by the Otter Brook Shear Zone, which emplaced the Annieopsquotch ophiolite belt over the slightly younger Lloyds River Complex of the
Annieopsquotch Accretionary Tract [Lissenberg et al., 2005a].

[9] The SESZ delineates the northwestern margin of the main bodies of the Annieopsquotch and Star Lake ophiolites, and is marked by a zone at least several hundred meters thick of numerous narrow $(\sim 0.1-1 \mathrm{~m})$ shear zones marked by strongly foliated amphibolites. The amphibolites are characterized by complete recrystallization of protolith clinopyroxene into fine-grained hornblende and strong grain size reduction of plagioclase. These shear zones are separated by less deformed and metamorphosed ophiolitic gabbros, which in many places largely retain their igneous texture of coarse-grained cumulus plagioclase and partially amphibolitized clinopyroxene. The ${ }^{40} \mathrm{Ar} /{ }^{39} \mathrm{Ar}$ hornblende ages suggest the amphibolites formed and cooled below $\sim 550^{\circ} \mathrm{C}$ by $471 \pm 5 \mathrm{Ma}$ [Lissenberg et al., 2005a]. Locally, the amphibolites are intruded by variably deformed veins and sheets of (quartz) diorite and associated tonalite. Where such intrusions occur, the amphibolites and intrusive rocks are generally strongly deformed, and intrusive veins are folded and deformed with the amphibolites (Figure 3). The age (459 $\pm 3 \mathrm{Ma}$; U/Pb zircon), arc-like geochemical signature, negative $\varepsilon_{\mathrm{Nd}}$, and the presence of inherited Paleoproterozoic zircons of the intrusions [Lissenberg et al., 2005a] contrast with the host amphibolite, whose protolith is older (480 Ma [Dunning and Krogh, 1985]) and has a mid-ocean ridge basalt-like, isotopically juvenile character [Lissenberg et al., 2005b]. These field and geochemical characteristics indicate the diorite-tonalite sheets are small-scale offshoots of the Pierre's Pond suite [Lissenberg et al., 2005a], whose main members occur between the NWSZ and CSZ (Figure 1). Around Star Lake, Pierre's Pond diorite-tonalite sheets are particularly abundant, and intruded outside the Lloyds River Fault Zone, directly into coarse- to very coarse-grained layered gabbro and pyroxenite cumulates of the Star Lake ophiolite (Figure 4). The sheets are generally $30-100 \mathrm{~cm}$ wide, commonly have steep dips, and generally strike northeast-

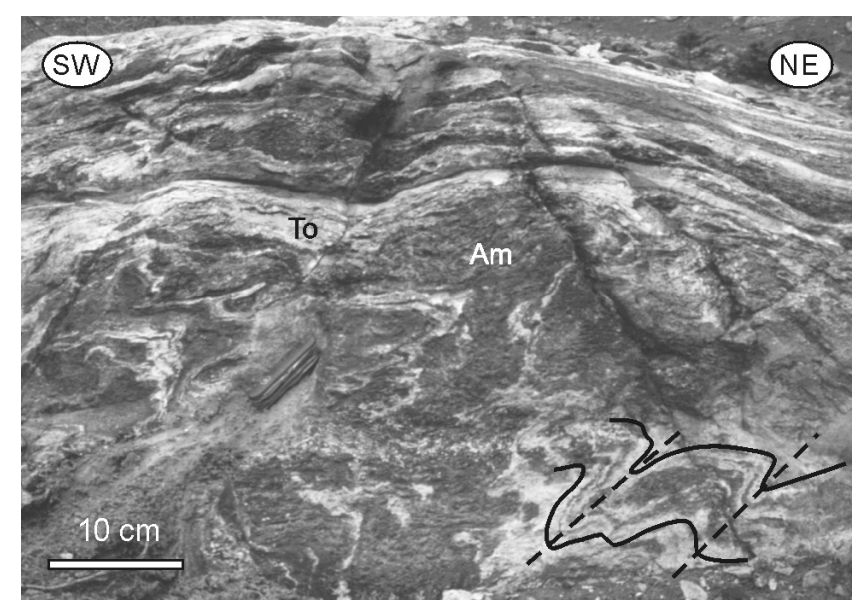

Figure 3. Highly strained amphibolite (Am)-tonalite (To) mylonite of the SESZ (top) grades into less well foliated amphibolite-tonalite tectonite (bottom). Note presence of folds in bottom right corner. 

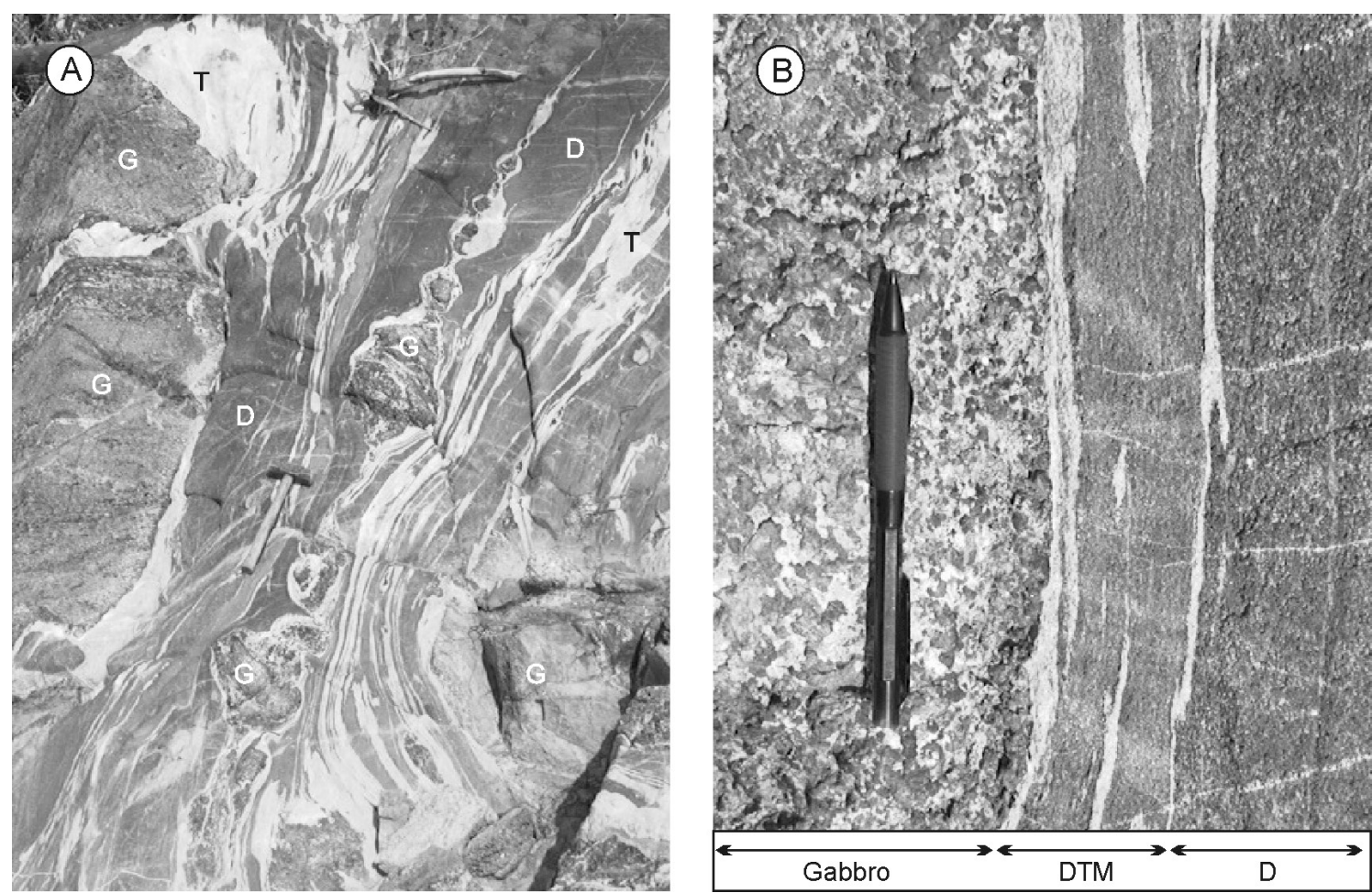

Figure 4. (a) Typical occurrence of Pierre's Pond intrusive sheets around Star Lake. Deformation is localized in decameter- to meter-wide diorites (D) and subordinate tonalites (T) that intrude gabbro (G) with igneous layering of the Star Lake ophiolite. Diorites contain relatively undeformed gabbro boudins, and tonalite veins are stretched and folded. (b) Close-up of the contact between ophiolitic gabbro and intrusive mylonitized diorite and tonalite (DTM) that grades into less deformed diorite (D). The large deformation contrast between the host gabbro and the diorite-tonalite mylonite suggests deformation localized in the diorites during synkinematic intrusion along the Lloyds River Fault Zone. Static greenschist-facies metamorphism in the gabbros is interpreted to result from contact metamorphism by the intrusive rocks.

southwest. The diorites are highly strained, with strong foliations generally parallel to the margins of the sheets, and commonly contain intrafolially folded and boudinaged tonalite veins (Figures 4 and 5). The highly strained character of the diorites and tonalites is in sharp contrast with the generally undeformed nature of the host gabbros (Figure 4b); only in a few outcrops are the host gabbros foliated as well. The host gabbros display cores of primary clinopyroxene $\left(\mathrm{En}_{45-52} \mathrm{Fs}_{7-8} \mathrm{Wo}_{40-47}\right)$ and plagioclase $\left(\mathrm{An}_{84-98}\right)$, that are partially replaced first by amphibolite-facies assemblages (hornblende rims on clinopyroxene) and then by randomly oriented greenschist-facies minerals such as actinolite, clinozoisite and chlorite (Table 1). This greenschist-grade metamorphic overprint is very prominent in the gabbros that occur near the intrusive sheets (within meters to tens of meters) and is generally absent in the rest of the Star Lake ophiolite. The undeformed nature of the gabbros, the randomly oriented greenschist-facies minerals, and the preserved primary mineral cores suggest the metamorphic episode was static and relatively short lived. These relationships suggest the diorites and tonalites intruded into the gabbros, localizing deformation in the intrusive rocks, and

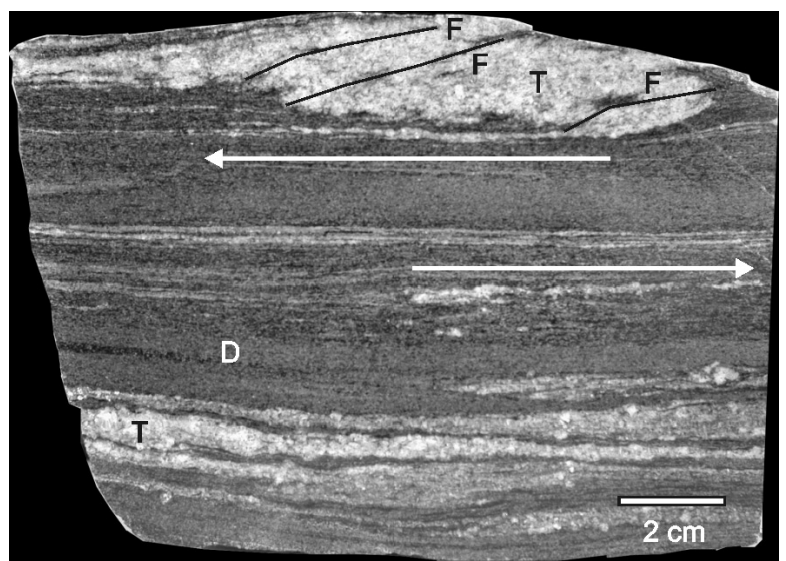

Figure 5. Polished hand sample of mylonitic Pierre's Pond suite diorite and tonalite from Star Lake, illustrating highly strained character of the diorite (D) and tonalite (T). Note folding (F) and stretching (arrows) of tonalite veins within the foliation planes. 


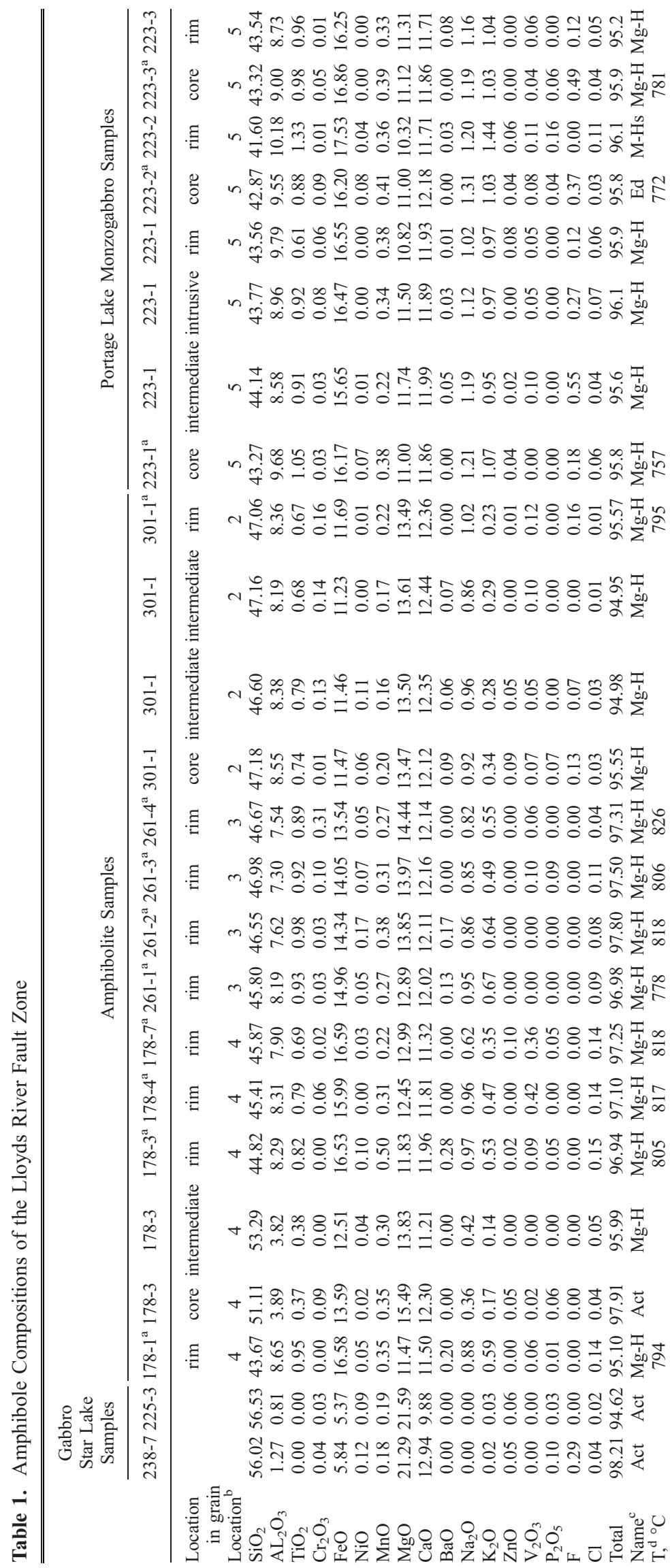




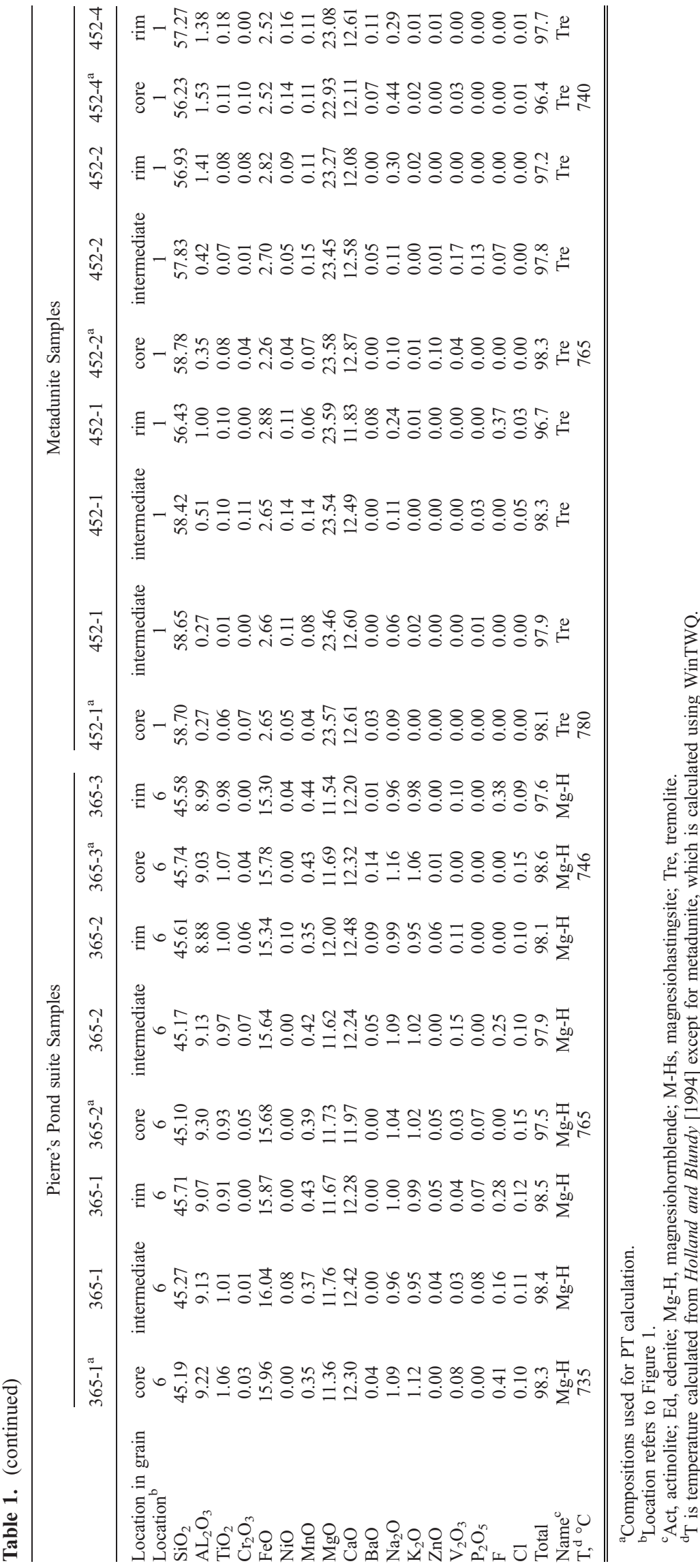




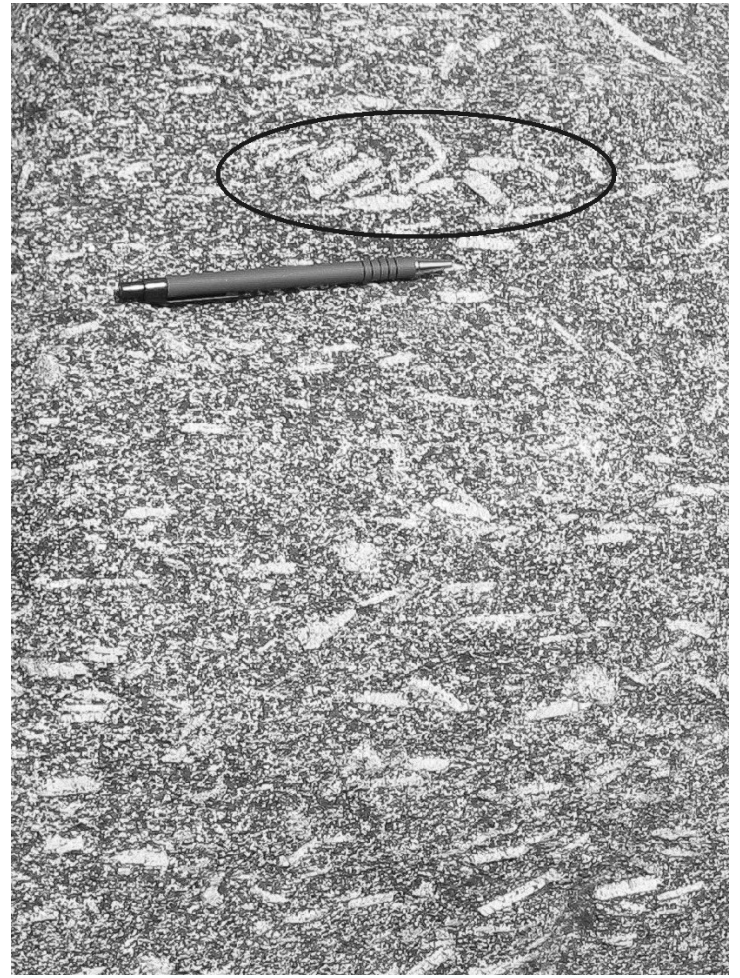

Figure 6. Foliation defined by K-feldspar phenocrysts with high aspect ratios in the Portage Lake monzogabbro. Note tiling of the phenocrysts (circled) and the low strain recorded in the matrix, indicative of deformation in the magmatic state.

triggering greenschist-facies contact metamorphism in the host gabbros. Since the diorite sheets also intrude into already deformed Lloyds River Fault Zone amphibolites, this strongly suggests that the diorites and tonalites intruded synkinematically into the Lloyds River Fault Zone after it had already accommodated movement at amphibolite-facies conditions. This is corroborated by the $459 \pm 3 \mathrm{Ma}$ age of a diorite from a synkinematic sheet [Lissenberg et al., 2005a], which is younger than the ${ }^{40} \mathrm{Ar} /{ }^{39} \mathrm{Ar}$ age of the Lloyds River Fault Zone amphibolites, and by evidence of magmatic deformation in the intrusive rocks (see below).

[10] The central shear zone (CSZ) predominantly marks the boundary between the Portage Lake monzogabbro and the Pierre's Pond suite (Figure 1). The Portage Lake monzogabbro is a variably deformed, elongate $(\sim 30 \times 5 \mathrm{~km})$, heterogeneous intrusive body that comprises an early finegrained facies followed by a voluminous phase of K-feldspar phyric monzogabbro to monzodiorite. The monzogabbro is generally weakly deformed in the interior of the pluton. The K-feldspar phenocrysts characteristically have large aspect ratios (5-15), generally define a foliation, and are locally tiled (Figure 6). In the weakly deformed part of the pluton, the phenocrysts have not recrystallized, yet they define a foliation subparallel to the Lloyds River Fault Zone (see below). This suggests that the Portage Lake monzogabbro was deformed in the magmatic state, possibly during synkinematic intrusion into the Lloyds River Fault Zone. This scenario is consistent with its age (464 \pm 2 and $462 \pm$ $2 \mathrm{Ma}, \mathrm{U} / \mathrm{Pb}$ zircon [Lissenberg et al., 2005a]), the presence of a foliated amphibolite enclave within the Portage Lake monzogabbro, presumably derived from nearby Lloyds River Fault Zone amphibolites, with microstructures (see below) and with the high aspect ratio of the pluton parallel to the Lloyds River Fault Zone. The northwestern margin of the pluton, along the CSZ, is marked by an amphibolitegrade high-strain zone of unknown thickness, which is dissected by several narrow ( $25 \mathrm{~cm}$ wide) chlorite + epidote-bearing shear zones. This indicates that deformation localized along the pluton margin during cooling.

[11] The northwestern shear zone (NWSZ) runs from King George IV Lake to northeast of Star Lake, and separates elongate bodies of variably metamorphosed ophiolitic gabbros and pyroxenites from the Notre Dame Arc and its Dashwoods microcontinent basement (Figure 1). The NWSZ is mostly marked by amphibolites and amphibolitized gabbro. Locally the amphibolites contain clinopyroxene, which has straight, clean grain boundaries against hornblende and plagioclase, commonly with $120^{\circ}$ angles, and has a composition distinct (i.e., higher Wo content) from primary clinopyroxene of Annieopsquotch gabbros. This indicates the clinopyroxene is of metamorphic origin. The amphibolites are best exposed northeast of King George IV Lake, where they form a mylonite zone that is at least $100 \mathrm{~m}$ thick. The amphibolites are intimately interlayered with veins and centimeter- to meter-wide sheets of highly deformed diorite and tonalite (Figure 7). On the basis of geochemical data of the larger sheets the diorites and tonalites are correlated with the Pierre's Pond suite. Ultramafic rocks, enclosed locally within the amphibolites, were generally transformed into olivine-tremolite, talctremolite-chlorite, and serpentine-talc assemblages.

[12] West of Star Lake, ophiolitic gabbros along the NWSZ are metamorphosed into chloritic phyllonites with abundant quartz veins. This suggests that deformation on this part of the NWSZ continued, or that it was reactivated, at lower temperature conditions. The segment where these phyllonites have been observed coincides with the part of the NWSZ that appears to be connected to the Little Grand Lake Fault, which separates different structural levels of the Notre Dame subzone [Brem et al., 2003] (see Figure 1). The Little Grand Lake Fault was reactivated, presumably in the Silurian, at shallow crustal levels after Early Middle Ordovician ductile movement [Brem et al., 2003]. Consequently, we infer that the chloritic phyllonites resulted from reactivation of the NWSZ after high-temperature deformation had ceased.

\subsection{Kinematic Interpretations}

[13] The foliation of the Lloyds River Fault Zone tectonites generally dips steeply to the northwest (Figure 8a). Southeast dipping foliations occur locally, but are restricted to an approximately $1 \mathrm{~km}$ long section of the NWSZ northeast of King George IV Lake. Lineations on the northwest dipping planes commonly plunge $40^{\circ}$ to $60^{\circ}$ to the north or northeast, whereas they plunge $40^{\circ}$ to $60^{\circ}$ to the 


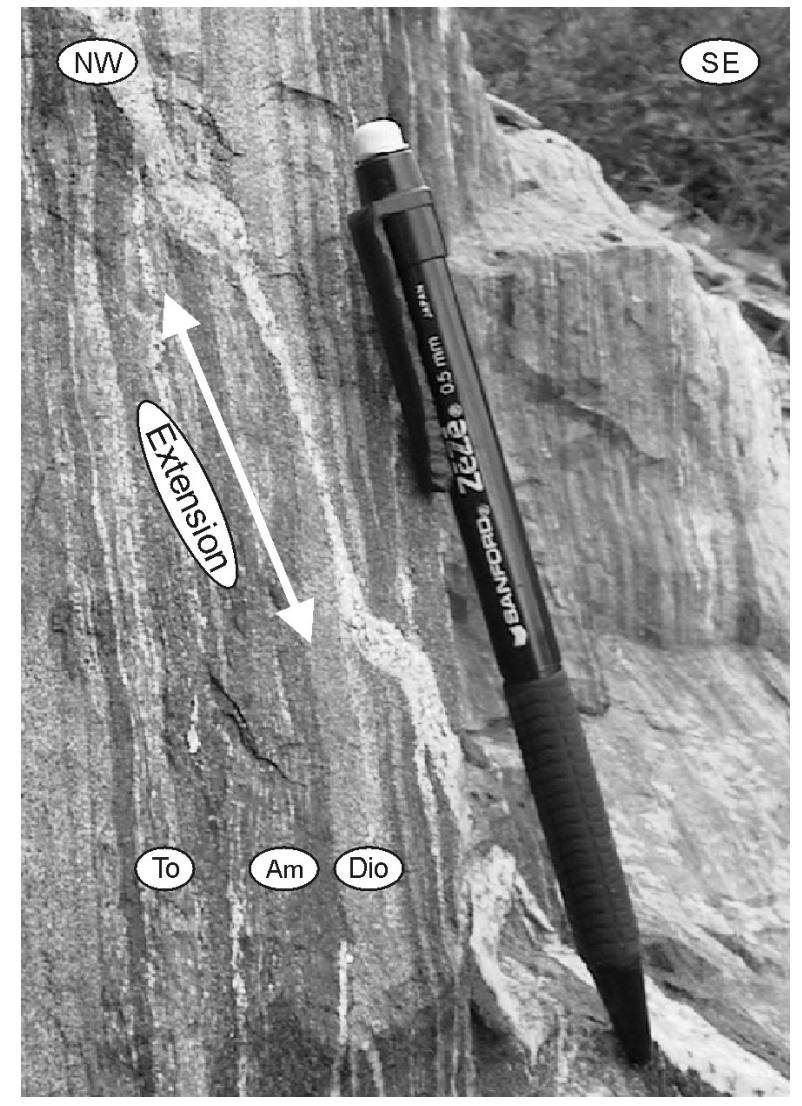

Figure 7. Typical gneissic tectonite of the NWSZ, composed of amphibolite (Am), diorite (Dio), and tonalite (To). Stretching of late kinematic felsic vein suggests the Annieopsquotch ophiolite belt, to the southeast, was moving down with respect to the Dashwoods microcontinent to the northwest. Vertical face, looking NE. south on southeast dipping planes (Figure 8a). Considering the geometrical constraints imposed by the regional-scale, linear outcrop pattern of the faults (Figure 1), as well as seismic sections indicating that the fault zone dips to the northwest [van der Velden et al., 2004], these data are most consistent with an overall northwest dipping, shear zonerelated foliation that is locally internally folded; with tight, asymmetric macroscopic folds resulting in steeply southeast dipping foliations. The presence of macroscopic folds within the shear zones is consistent with their local occurrence on microscopic and mesoscopic scale.

[14] Shear sense indicators are best developed within the NWSZ, where deformed diorite and tonalite are intimately interlayered with amphibolites, producing a gneissic layering. The obliquity of the instantaneous extension direction determined from late kinematic stretched veins in the northwest dipping foliation, and locally also by shear bands and asymmetrical boudinage, indicates that the Annieopsquotch ophiolite belt was thrust beneath the Dashwoods microcontinent (Figure 7). This is in keeping with (1) shear bands observed in amphibolites of the SESZ, which also indicate underthrusting of the Annieopsquotch ophiolite belt (Figure 9) and (2) the $Z$ asymmetry of intrafolial folds on vertical faces and the $S$ asymmetry of such folds on horizontal faces. These folds have curviplanar axial surfaces, and change from open to very tight over short distances (Figures 9 and 10), suggesting that they are drag folds with fold axes at a high angle to the lineation. The north to northeast plunge of the lineations on the northwest dipping foliation planes, combined with underthrusting of the Annieopsquotch ophiolite belt, suggests the Lloyds River Fault Zone also accommodated a component of sinistral strike slip. Alternatively, the moderate to steep pitch of the stretching lineation could have formed in an oblique transpression zone with triclinic symmetry that mainly accommodated strike slip shear [Lin et al., 1998]. However, a significant dip slip component is required to account for the great depth to which the Annieopsquotch ophiolite belt was

\section{A) LRFZ tectonites}

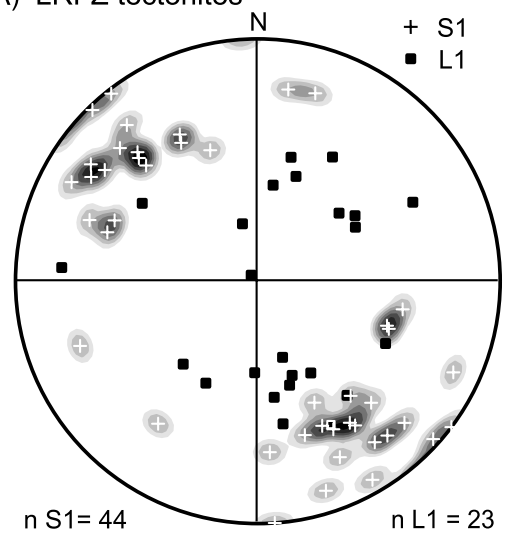

B) Syn-kinematic

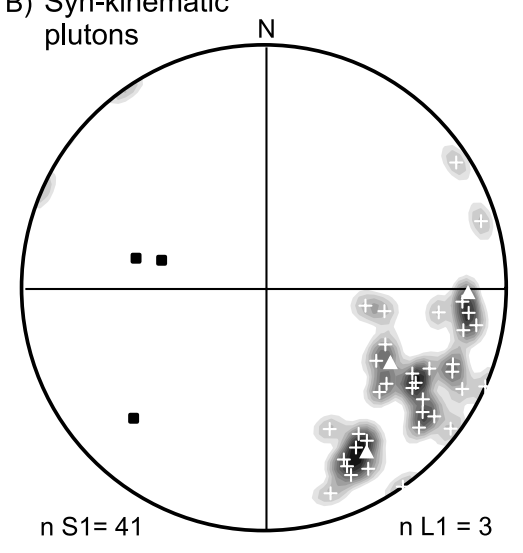

C) Intrusive sheets

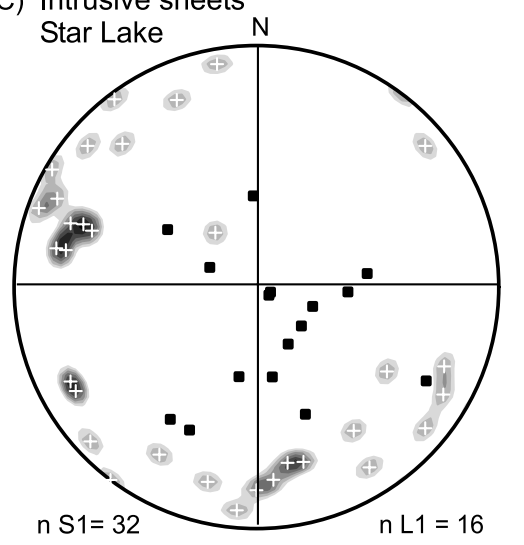

Figure 8. Lower hemisphere equal area plots of structures of the Lloyds River Fault Zone. (a) Lineation (squares) and poles to foliation (crosses) of Lloyds River Fault Zone tectonites. (b) Lineation and poles to foliation in synkinematic intrusive sheets. Poles to magmatic foliation of the Portage Lake monzogabbro are indicated by triangles. (c) Lineation and poles to foliation of diorite-tonalite hosted shear zones around Star Lake. 


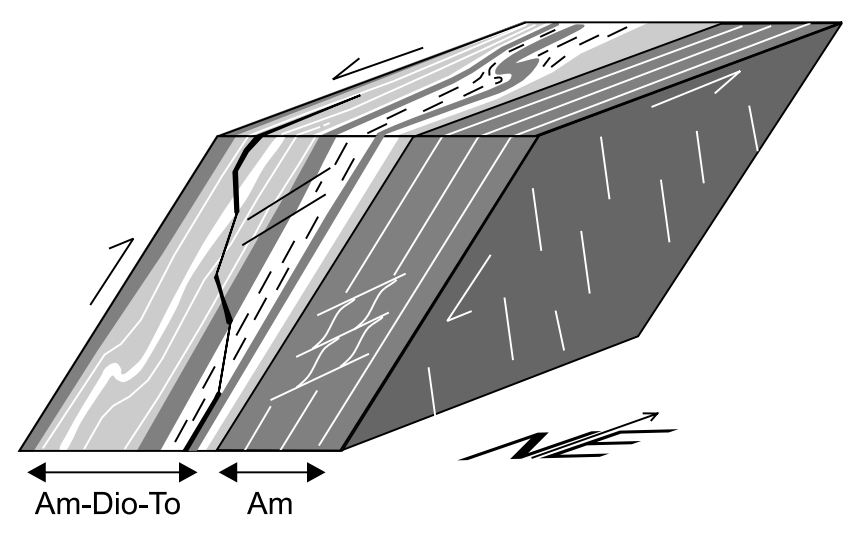

Figure 9. Schematic block diagram summarizing the various structures observed within amphibolites (Am, dark grey) and amphibolite-diorite-tonalite (Am-Dio-To, dark grey, light grey, and white, respectively) tectonites of the Lloyds River Fault Zone. Stretched late kinematic vein is indicated in black.

transported (at least $33 \mathrm{~km}$; exposed rocks represent a paleodepth of $\sim 18 \mathrm{~km}$ (see below) and the belt extends to $\sim 15 \mathrm{~km}$ depth [van der Velden et al., 2004]).

[15] Foliations within the Portage Lake monzogabbro (magmatic and solid state) and Pierre's Pond suite (solid state) dip moderately to steeply to the northwest, similar to the foliation in the amphibolites (Figure 8b). Foliations in the small diorite-tonalite sheets in the SESZ near Star Lake dominantly strike northeast-southwest, conform the general trend of the Lloyds River Fault Zone, but dip both northwest and southeast because they are generally parallel to the margins of the intrusions, which have somewhat variable orientations (Figure 8c). The shear zones are generally steep, as are lineations defined by amphibole, suggesting a dominantly dip-slip motion.

[16] Sinistral oblique underthrusting of the Annieopsquotch ophiolite belt interpreted along the Lloyds River Fault Zone is consistent on a regional scale with (1) relationships along strike, where the northeasterly extension of the Lloyds River Fault Zone, the Hungry Mountain thrust, shows similar thrusting motion [Thurlow, 1981; Thurlow et al., 1992; Calon and Green, 1987; Whalen et al., 1987]; (2) sinistral-oblique reverse motion documented for the Otter Brook Shear Zone [Zagorevski and van Staal, 2002], which bounds the Annieopsquotch ophiolite belt to the southeast, and is in part coeval with the Lloyds River Fault Zone [Lissenberg et al., 2005a]; (3) the Lithoprobe seismic reflection profile, which shows that the Annieopsquotch ophiolite belt extends underneath the Dashwoods microcontinent to $15 \mathrm{~km}$ depth (Figure 2).

\subsection{Microstructures}

[17] Amphibolites of the Lloyds River Fault Zone are generally characterized by fine-grained hornblende and plagioclase. Locally, partially to completely recrystallized aggregates of small metamorphic plagioclase $(0.1-0.3 \mathrm{~mm})$ have pseudomorphed igneous plagioclase laths. Most amphibolites have a single foliation defined by well-developed shape and lattice preferred orientations of hornblende and to a lesser extent elongate plagioclase aggregates (Figure 11a). Highly strained amphibolites are generally marked by strong grain size reduction and elongation (hornblende with aspect ratios up to 15; Figure 11a). Relict large plagioclase crystals behaved as rigid objects wrapped by the foliation. Locally the amphibolites show a crenulation cleavage, with the younger schistosity axial planar to open to tight microfolds developed in the older hornblende schistosity. Euhedral hornblende crystals (generally $0.5-$ $1 \mathrm{~mm}$ ) have overgrown both foliations, suggesting shear zone development, folding and development of a transposition foliation took place under amphibolite-facies conditions, consistent with them forming part of a progressive deformation that is preferentially localized in the shear zones. Hornblende porphyroclasts in the relatively low strain domains show subgrains and tails comprising fine grained aggregates of neoblasts (Figure 11b), suggesting that rotation recrystallization [Urai et al., 1986] together with new grain growth contributed to the foliation development in the shear zones. Some amphibolites in contact with intrusive sheets experienced high degrees of plastic deformation. These amphibolites have a strong foliation, defined by long axes of amphiboles, which is locally folded with intrusive tonalite (Figure 11c). Whereas most amphibolites retain their shape-preferred orientation, feldspars within some samples have been partly to completely recrystallized into polygonal aggregates with $120^{\circ}$ grain boundaries. This suggests that temperatures remained high in these gabbros, or that they experienced reheating, after deformation had ceased.

[18] The Portage Lake monzogabbro preserves a range of deformation states from near-magmatic to completely recrystallized in the solid state. Samples with limited solid-state deformation preserve aligned K-feldspar phenocrysts (up to $2 \mathrm{~cm}$ long) with high aspect ratios (up to 6) that are recrystallized only along their margins. Internally, the

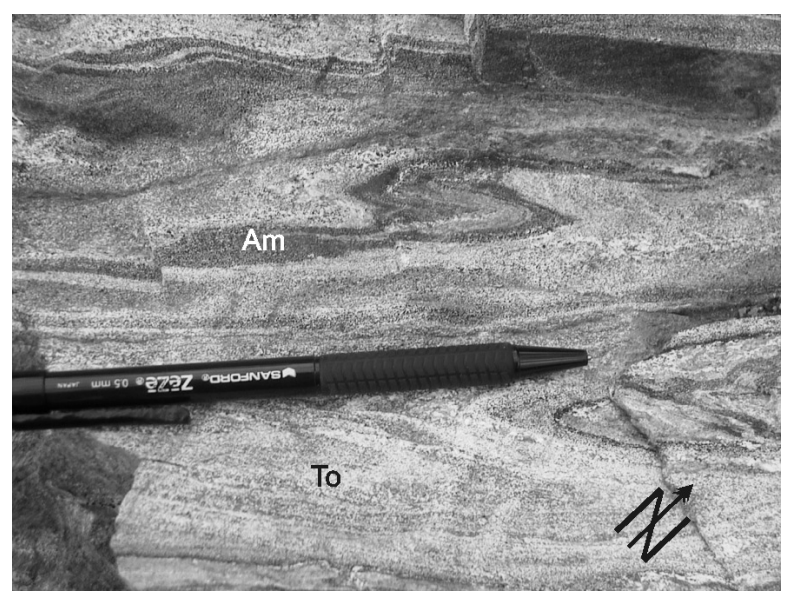

Figure 10. Intrafolial fold in amphibolite (Am)-tonalite (To) tectonite of the NWSZ changes from tight (in center) to open (in top left corner), suggesting it formed by sinistral drag. Horizontal plane. 

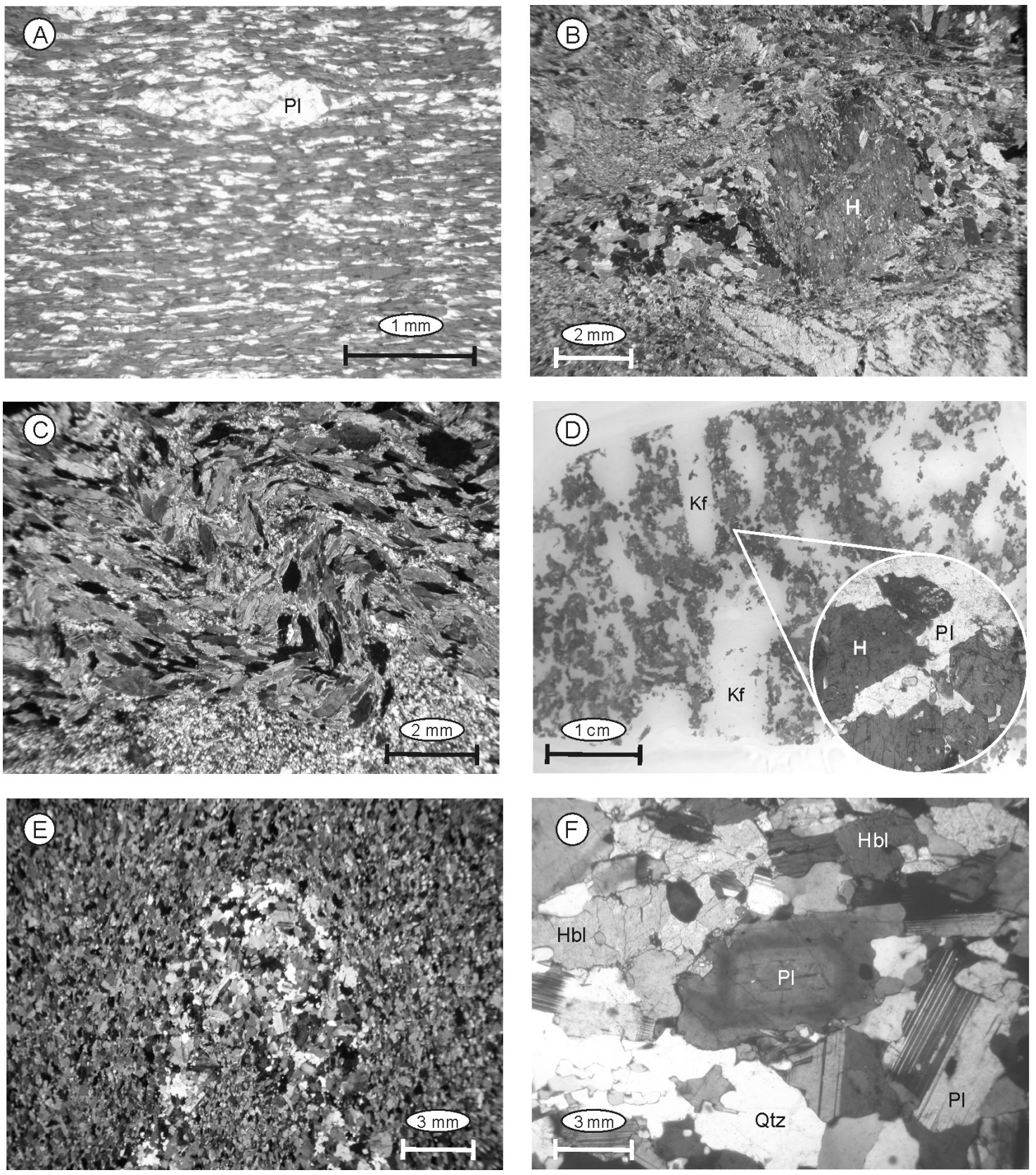

Figure 11. Microstructures in amphibolites and synkinematic plutons of the Lloyds River Fault Zone. (a) Highly strained amphibolite shows extreme grain size reduction and stretching, yielding highly elongate hornblende and plagioclase. A relict large plagioclase grain (Pl) serves as relatively rigid object, and is recrystallized into small grains. Plane polarized light. (b) Hornblende porphyroclast (H) with tail of recrystallized hornblende grains in SWSZ amphibolite. Crossed polars. (c) Folded amphibolite-tonalite tectonite. Crossed polars. (d) Thin section of Portage Lake monzogabbro shows parallel K-feldspar phenocrysts $(\mathrm{Kf})$ that define a foliation (vertical) within a matrix that lacks shape-preferred orientations, and preserves euhedral hornblende (inset). Plane polarized light. (e) Folded tonalite vein in diorite. Crossed polars. (f) Close-up of tonalite vein of (E), showing oscillatory zoning in plagioclase ( $\mathrm{Pl})$ and limited solid-state deformation within the plagioclase (Pl)-quartz (Qtz)-hornblende (Hbl) matrix. Crossed polars. 
phenocrysts are undeformed, preserve Carlsbad twins, lack microcline twinning, and enclose euhedral hornblende. The phenocrysts are set in a hornblende+feldspar+biotite matrix that lacks shape-preferred orientations, and preserves euhedral hornblende crystals (Figure 11d). These features suggest $\mathrm{K}$-feldspar fabric development during deformation in the magmatic state [Vernon, 2000]. Extensive solid-state deformation has led to complete recrystallization of phenocrysts into fine-grained K-feldspar aggregates in most samples.

[19] The Pierre's Pond suite diorites and tonalites that have intruded the ophiolitic gabbros around Star Lake generally show large degrees of solid-state deformation characterized by strong shape-preferred orientations, grain size reduction, formation of S-C fabrics, and foliation that wraps around large, partially recrystallized relict igneous plagioclase crystals, that are now best described as porphyroclasts. Foliations in these rocks are generally defined by aligned biotite and hornblende, and to a lesser extent elongate plagioclase \pm quartz aggregates. In some samples this foliation is overprinted by shear bands mainly defined by chlorite and/or epidote. Nevertheless, evidence for deformation occurring while the rock was still partially in a magmatic state appears to be locally preserved in the synkinematic intrusions. Tightly to isoclinally folded tonalite veins in strongly foliated diorite (Figure 11e) contain elongate plagioclase grains that can be traced around the fold hinges, yet have locally preserved oscillatory zoning and show little to moderate recrystallization only along their grain boundaries, despite showing abundant deformation twinning (Figure 11f). Quartz grains are generally equidimensional with minor subgrain formation and recrystallization. This contrasts with the hornblende-plagioclase fabric in the host diorite, which displays a strong hornblendedefined fabric tracing the fold hinges. The preservation of primary igneous textures such as oscillatory zoning within aligned plagioclase displaying little internal strain besides twinning, suggest that fabric formation in the folded tonalite veins did not occur entirely by solid-state deformation but probably started in the magmatic state.

\section{Pressure-Temperature Conditions}

\subsection{Analytical Techniques}

[20] Mineral compositions were analyzed by electron microprobe at the Geological Survey of Canada (Ottawa) using a wavelength-dispersive Cameca SX-50, a mixture of natural and synthetic standards, and ZAF matrix correction procedures described by Armstrong [1988]. Accelerating voltage and beam current were $20 \mathrm{kV}$ and $10 \mathrm{nA}$, respectively, and counting time was $15 \mathrm{~s}$. Olivine and pyroxene were analyzed with a focused beam, plagioclase and amphibole with a $10 \mu \mathrm{m}$ beam spot. Results are listed in Table 1 (amphibole), Table 2 (plagioclase), and Table 3 (clinopyroxene and olivine).

\subsection{Geothermobarometry}

[21] Temperature constraints on accretion of the Annieopsquotch ophiolite belt are provided by the amphib- olites that mark the SESZ and NWSZ (Figure 1). The amphibolites are commonly composed of magnesiohornblende and plagioclase (typically $\mathrm{An}_{45-55}$; Tables 1 and 2) that define the main foliation of the shear zones. Grain boundaries are generally straight, clean, and lack evidence for reaction or alteration, suggesting the phases were in equilibrium. In some samples, plagioclase displays normal zoning, with highly saussuritized cores with anorthite contents up to 69 to fresh rims with anorthite contents of $\sim 50$. This may result from partial reequilibration of primary highAn cumulus crystals during metamorphism. In other samples, reverse zoning is marked by cores of oligoclase $\left(\mathrm{An}_{14}\right)$ with epidote inclusions rimmed by zoned plagioclase $\left(A n_{47-56}\right)$, and actinolite cores rimmed by magnesiohornblende with increasing Al content toward the rim. We interpret the oligoclase and actinolite cores as prograde mineral compositions, recording early greenschist-facies metamorphism partially overprinted by amphibolite-facies assemblages.

[22] Hornblende-plagioclase thermometry (edenite + albite $=$ richterite + anorthite [Holland and Blundy, 1994]) using rim compositions of three amphibolites yields temperatures of $778^{\circ} \mathrm{C}$ to $826^{\circ} \mathrm{C}$, with an average of $806^{\circ} \mathrm{C}$ (assuming $\mathrm{P}=5 \mathrm{kbar}$; Tables 1-2). The different temperatures result from small compositional variations in plagioclase $( \pm 4 \mathrm{~mol} \% \mathrm{An})$ and amphibole $\left( \pm 0.09 \mathrm{Al}^{\mathrm{T}}\right.$ and \pm 0.04 $\mathrm{Na}$ ), but fall within the uncertainty of the thermometer $\left( \pm 40^{\circ} \mathrm{C}\right.$ [Holland and Blundy, 1994]). Despite the high temperatures, (metamorphic) clinopyroxene is absent in all but one of the amphibolites. This likely results from (1) the quartz undersaturated nature of the rocks, which increases the stability field of hornblende such that the cpx-in reaction lies at $\sim 800^{\circ} \mathrm{C}$ at $\mathrm{P}>2 \mathrm{kbar}$ and $\mathrm{fO}_{2}=\mathrm{QFM}$ [Spear, 1981]; (2) the high $\mathrm{Mg}$ \# of the amphibole (average 76), which suppresses the appearance of pyroxene to higher temperatures [Spear, 1981]; and (3) high $\mathrm{P}_{\mathrm{H} 2 \mathrm{O}}$ within the shear zone, which has a stabilizing effect on hornblende.

[23] Additional constraints on the temperatures recorded by the amphibolites are provided by a metadunite, composed of olivine and a small amount of acicular tremolite, which is enclosed within metagabbros of the NWSZ. Olivine $\left(\mathrm{Fo}_{86-87}\right.$; Table 3$)$ in the metadunite is unzoned to very weakly zoned, and, whereas tremolite shows increasing $\mathrm{Al}$ contents toward the rim, its $\mathrm{Mg}$ \# remains essentially constant ( $\mathrm{Mg} \#=0.94-0.96$; Table 1). Fe-Mg exchange between the olivine and tremolite, calculated using WinTWQ [Berman, 1988, 1991; Mader and Berman, 1992] indicates equilibration temperatures between 740 and $780^{\circ} \mathrm{C}$. These temperatures support the upper amphibolite-facies temperatures derived from the amphibolites.

[24] Pressure constraints are provided by a clinopyroxene-bearing amphibolite from the NWSZ, composed of magnesiohornblende, diopside $\left(\mathrm{En}_{38-42} \mathrm{Wo}_{49-50} \mathrm{Fs}_{9-13}\right.$; Table 3$)$ and calcic plagioclase $\left(\mathrm{An}_{85-94}\right)$. Pressure conditions are estimated by intersecting the hornblende-plagioclase thermometer [Holland and Blundy, 1994] with reactions between hornblende, plagioclase and clinopyroxene calculated using WinTWQ. We used the reaction 5 Fe-tschermakite +8 diopside +2 albite $=8$ anorthite + 3 Fe-tremolite +2 pargasite, since this reaction (1) has the 


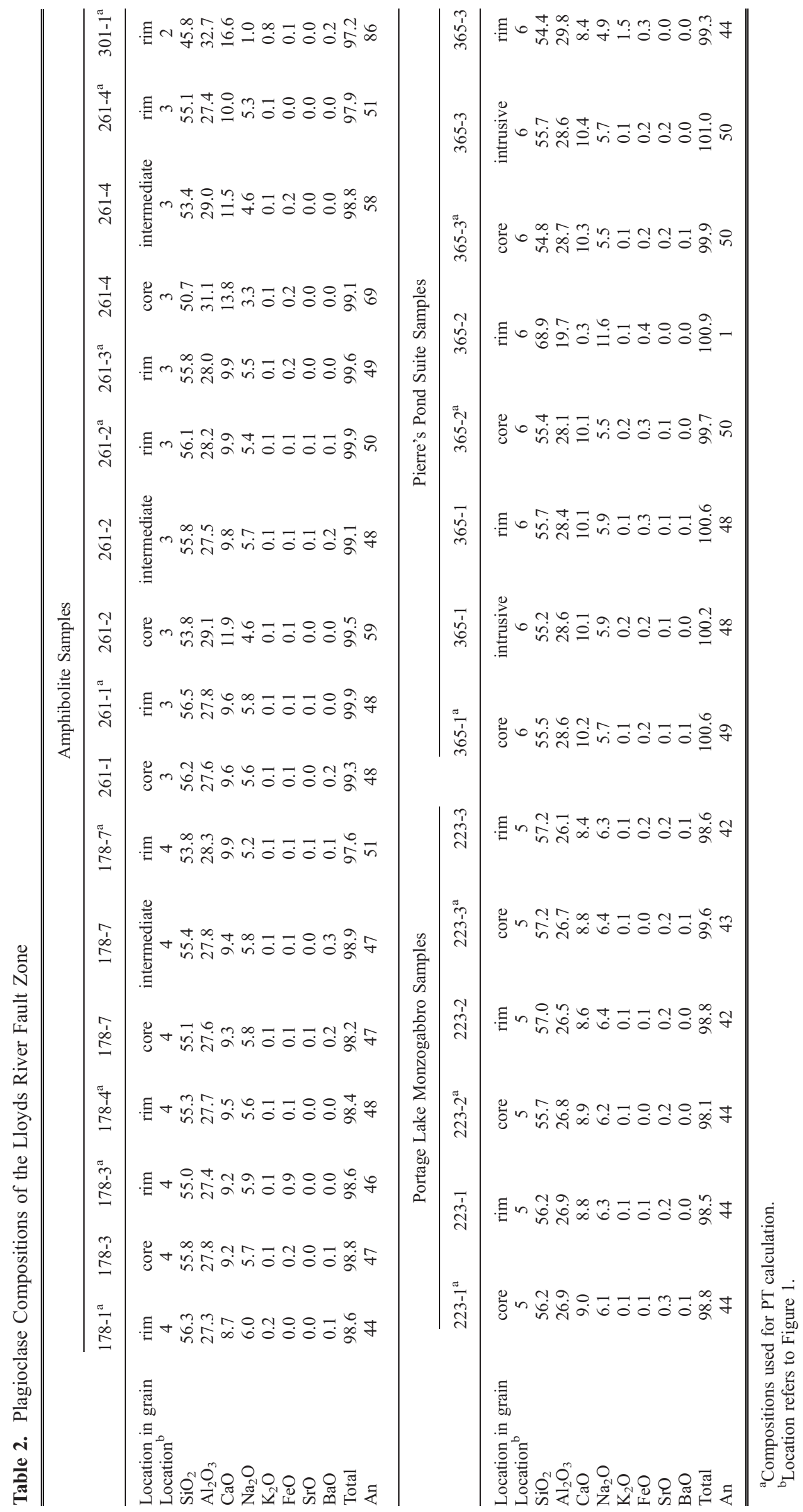


Table 3. Olivine and Clinopyroxene Compositions of the Lloyds River Fault Zone

\begin{tabular}{|c|c|c|c|c|c|c|c|c|c|c|c|c|}
\hline & \multicolumn{10}{|c|}{ Olivine (Metadunite Sample) } & \multicolumn{2}{|c|}{$\begin{array}{c}\text { Clinopyroxene } \\
\text { (Amphibolite } \\
\text { Sample) }\end{array}$} \\
\hline & $452-1^{\mathrm{a}}$ & $452-1$ & $452-1$ & $452-2^{\mathrm{a}}$ & $452-2$ & $452-2$ & $452-4^{\mathrm{a}}$ & $452-4$ & $452-4$ & $452-4$ & $301-1$ & $301-1^{\mathrm{a}}$ \\
\hline Location in grain & core & core & core & & rim & rim & & core & intermediate & rim & core & rim \\
\hline Location $^{\mathrm{b}}$ & 1 & 1 & 1 & 1 & 1 & 1 & 1 & 1 & 1 & 1 & 2 & 2 \\
\hline $\mathrm{SiO}_{2}$ & 40.25 & 40.41 & 40.75 & 39.80 & 39.76 & 39.44 & 39.76 & 39.69 & 39.94 & 39.70 & 51.87 & 53.05 \\
\hline $\mathrm{AL}_{2} \mathrm{O}_{3}$ & 0.07 & 0.07 & 0.04 & 0.04 & 0.05 & 0.01 & 0.03 & 0.03 & 0.06 & 0.06 & 1.52 & 1.16 \\
\hline $\mathrm{TiO}_{2}$ & 0.06 & 0.07 & 0.03 & 0.00 & 0.00 & 0.01 & 0.02 & 0.03 & 0.04 & 0.04 & 0.12 & 0.14 \\
\hline $\mathrm{CaO}$ & 0.02 & 0.00 & 0.00 & 0.00 & 0.02 & 0.00 & 0.00 & 0.00 & 0.02 & 0.00 & 23.84 & 23.78 \\
\hline $\mathrm{MgO}$ & 46.09 & 45.91 & 46.24 & 46.00 & 46.29 & 45.88 & 46.24 & 46.03 & 46.10 & 46.31 & 13.35 & 13.62 \\
\hline $\mathrm{FeO}$ & 12.73 & 12.70 & 12.85 & 12.58 & 13.16 & 13.03 & 12.46 & 12.77 & 12.96 & 12.84 & 7.30 & 6.82 \\
\hline $\mathrm{Na}_{2} \mathrm{O}$ & 0.01 & 0.03 & 0.00 & 0.02 & 0.01 & 0.00 & 0.01 & 0.04 & 0.03 & 0.00 & 0.27 & 0.25 \\
\hline $\mathrm{K}_{2} \mathrm{O}$ & 0.03 & 0.00 & 0.00 & 0.00 & 0.00 & 0.00 & 0.02 & 0.01 & 0.00 & 0.00 & 0.00 & 0.02 \\
\hline $\mathrm{MnO}$ & 0.10 & 0.20 & 0.19 & 0.20 & 0.17 & 0.23 & 0.19 & 0.08 & 0.14 & 0.26 & 0.15 & 0.31 \\
\hline $\mathrm{Cr}_{2} \mathrm{O}_{3}$ & 0.00 & 0.03 & 0.04 & 0.01 & 0.00 & 0.05 & 0.00 & 0.12 & 0.00 & 0.00 & 0.05 & 0.04 \\
\hline $\mathrm{NiO}$ & 0.32 & 0.29 & 0.37 & 0.45 & 0.31 & 0.39 & 0.34 & 0.27 & 0.36 & 0.25 & 0.00 & 0.00 \\
\hline $\mathrm{V}_{2} \mathrm{O}_{3}$ & 0.07 & 0.00 & 0.00 & 0.00 & 0.03 & 0.03 & 0.00 & 0.00 & 0.00 & 0.07 & 0.05 & 0.09 \\
\hline Total & 99.76 & 99.71 & 100.51 & 99.10 & 99.82 & 99.05 & 99.07 & 99.07 & 99.65 & 99.52 & 100.27 & 99.28 \\
\hline Fo & 86.6 & 86.6 & 86.5 & 86.7 & 86.2 & 86.3 & 86.9 & 86.5 & 86.4 & 86.5 & & - \\
\hline En & - & - & - & - & - & - & - & - & - & - & 39 & 39 \\
\hline Fs & - & - & - & - & - & - & - & - & - & - & 12 & 12 \\
\hline Wo & - & - & - & - & - & - & - & - & - & - & 49 & 49 \\
\hline
\end{tabular}

${ }^{\mathrm{a}}$ Compositions used for PT calculation.

${ }^{\mathrm{b}}$ Location refers to Figure 1.

largest $\Delta \mathrm{V}$ and is thus most pressure sensitive; (2) has diopside as the only pyroxene end-member (this should make the pressure estimate more robust since the activity of diopside is much larger than that of hedenbergite in the pyroxenes analyzed); and (3) has pargasite as amphibole end-member, which is thermodynamically better characterized than the Fe-pargasite end-member used in other reactions. The intersection between the hornblende-plagioclaseclinopyroxene reaction described above and the hornblendeplagioclase thermometer suggest the amphibolite was equilibrated at $\sim 790^{\circ}$ and $6 \mathrm{kbar}$ (Figure 12). The uncertainty of $\mathrm{P}$ as a result of compositional heterogeneity and analytical uncertainty was estimated by varying mineral compositions: varying $\mathrm{Mg} / \mathrm{Fe}$ contents of clinopyroxene + amphibole and An content of plagioclase by $4 \mathrm{~mol} \%$ indicates an uncertainty of $\sim 1.5 \mathrm{kbar}$.

[25] High-temperature conditions similar to those of the amphibolites are recorded within samples of the Portage Lake monzogabbro and Pierre's Pond suite that have been deformed in the solid state. Amphiboles in the Portage Lake monzogabbro have Si contents around 1.5 and A site occupancy around 0.5 , defining the amphiboles as edenite, tschermakite, magnesiohornblende, and magnesiohastingsite [cf. Leake et al., 1997]. Some amphiboles are subtly zoned from edenitic cores to magnesiohastingsite or magnesiohornblende rims. Plagioclase is $\sim \mathrm{An}_{45}$ in cores, and $\mathrm{An}_{40}$ in rims and small matrix grains. K-feldspar is generally $\mathrm{Or}_{88-90}$, but small grains and rims have orthoclase contents up to 94 . This suggests minor reequilibration of hornblende, plagioclase and K-feldspar occurred. Therefore core compositions have been used for geothermometry. Hornblende-plagioclase thermometry of core compositions yielded temperatures between $757-781^{\circ} \mathrm{C}$, with an average of $770^{\circ} \mathrm{C}$ (assuming $\mathrm{P}=5 \mathrm{kbar}$ ). Rim compositions yielded temperatures within error $\left( \pm 40^{\circ} \mathrm{C}\right)$ of the core composition temperatures. Two-feldspar thermometry [Fuhrman and Lindsley, 1988] yields lower temperatures, due to low orthoclase activity in plagioclase and low anorthite activity in K-feldspar, suggesting that these feldspars reequilibrated. These lower temperatures can be explained by up to $4 \mathrm{~mol}$ $\% \mathrm{~K}-\mathrm{Na}$ exchange between the two feldspars. We note that reequilibration of $4 \mathrm{~mol} \% \mathrm{Na}$ changes the results of the

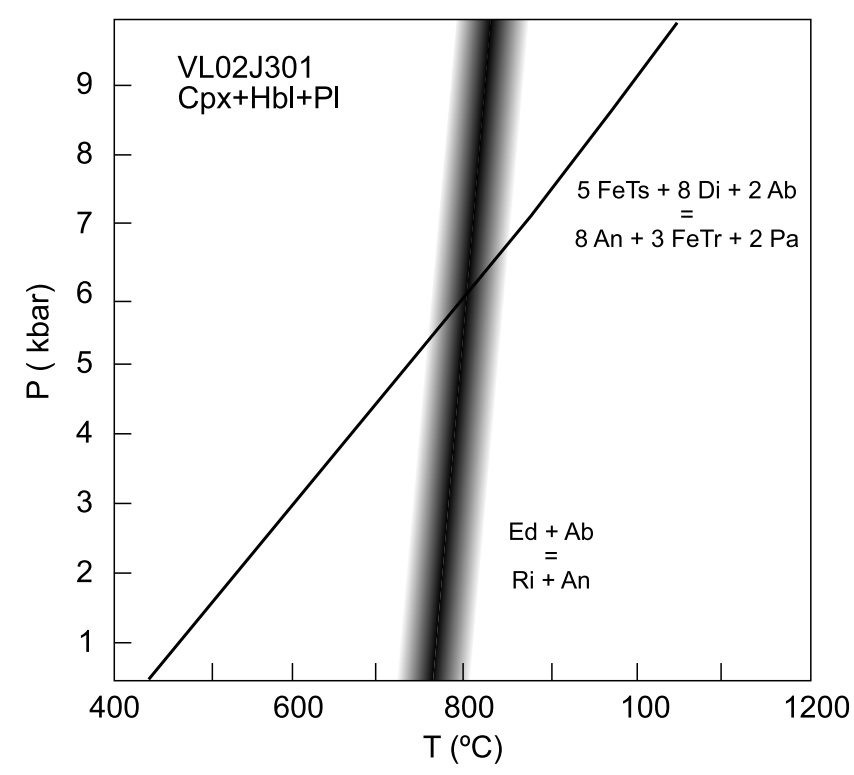

Figure 12. Diagram illustrating PT conditions calculated for amphibolite VL02J301. Grey field represents the uncertainty of the hornblende-plagioclase thermometer. 
hornblende-plagioclase temperatures by only $10^{\circ}$, well within the uncertainty involved in the thermometer $\left( \pm 40^{\circ} \mathrm{C}\right.$ [Holland and Blundy, 1994]).

[26] Hornblende from the Pierre's Pond suite diorites is weakly zoned magnesiohornblende to tschermakite, and plagioclase compositions are $\mathrm{An}_{48^{-}} 50$ in cores, ranging to $\mathrm{An}_{44}$ in rims (Tables 1-2) The Holland and Blundy [1994] geothermometer, using core compositions, indicates the diorites were deformed at temperatures of $735-765^{\circ} \mathrm{C}$ (average $748^{\circ} \mathrm{C}$, assuming $\mathrm{P}=5 \mathrm{kbar}$ ). Rim compositions yielded temperatures within error $\left( \pm 40^{\circ} \mathrm{C}\right)$ to slightly lower temperatures $\left(\sim 700^{\circ} \mathrm{C}\right)$. Deformation in the Portage Lake monzogabbro and Pierre's Pond suite continued at lower temperature, indicated by actinolite and albite rims on some grains and the formation of cleavage planes marked by greenschist-facies minerals (chlorite + epidote) in some samples.

\section{Synthesis and Discussion}

\subsection{Structural Evolution of the Lloyds River Fault Zone}

[27] The data presented in this paper, combined with the geochronological data presented by Lissenberg et al. [2005a], allow the structural evolution of the Lloyds River Fault Zone to be reconstructed. The structures and mineral compositions of the amphibolites indicate that the Lloyds River Fault Zone records underthrusting of the Annieopsquotch ophiolite belt beneath the composite Laurentian margin at temperatures of $\sim 800^{\circ} \mathrm{C}$ and pressures of $\sim 6 \mathrm{kbar}$. Underthrusting is consistent with both interpretations of seismic data and structural relationships along strike to the northwest of the study area [Dean and Strong, 1977; Thurlow et al., 1992; van der Velden et al., 2004], and was thus a regional tectonic phenomenon. Convergence between the Annieopsquotch ophiolite belt and the composite Laurentian margin that led to formation of the Lloyds River Fault Zone probably started in response to a plate reorganization following the collision between the Dashwoods microcontinent and the Laurentian margin, which had started by at least by $475 \mathrm{Ma}$ [Waldron and van Staal, 2001; van Staal et al., 2003; Lissenberg et al., 2005b]. Such a tectonic scenario is consistent with the ${ }^{40} \mathrm{Ar} /{ }^{39} \mathrm{Ar}$ ages, which suggest that underthrusting must have started prior to $471 \pm 5 \mathrm{Ma}$, when the rocks cooled below $\sim 550^{\circ} \mathrm{C}$ [Lissenberg et al., 2005a].

[28] Both the preservation of high-temperature fabrics and old cooling ages within the SESZ amphibolites indicates that, after $471 \mathrm{Ma}$, movement on the Lloyds River Fault Zone was either localized under lower temperature conditions $\left(<550^{\circ} \mathrm{C}\right)$ in narrow shear zone segments currently not preserved as a result of assimilation into synkinematic intrusions, or that movements had ceased all together. However, a renewed phase of high-temperature deformation must have taken place at least locally between 464 and $462 \mathrm{Ma}$ when the Portage Lake monzogabbro intruded the Lloyds River Fault Zone, which significantly weakened the shear zone. Deformation was initially by magmatic flow within the weak, not yet completely solid- ified pluton, leading to the magmatic alignment of $\mathrm{K}$ feldspar phenocrysts subparallel to Lloyds River Fault Zone, before an episode of solid-state deformation. The high temperatures recorded by the metamorphic mineral assemblages in the core of the pluton $\left(\sim 770^{\circ} \mathrm{C}\right)$, and the local preservation of magmatic fabrics, suggest this episode was relatively short lived. Solid-state deformation continued along the pluton margin at lower temperatures, forming a narrow epidote-chlorite mylonite zone.

[29] At $459 \pm 3 \mathrm{Ma}$, the diorites and subordinate tonalites of the Pierre's Pond suite intruded into the Lloyds River Fault Zone. We note that, even though one of the two ages of the Portage Lake monzogabbro overlaps the age of the Pierre's Pond suite, the latter is most likely younger; the probability of the two suites being of the same age is 0.016 . On a large scale, Pierre's Pond suite magmatism is expressed by the elongated diorite-tonalite sheet that occurs between the NWSZ and CSZ. On a small scale, the suite formed decameter- to meter-sized intrusive sheets and veins within the amphibolites, and intruded the underformed ophiolitic gabbros near Star Lake [Lissenberg et al., 2005a]. Like the Portage Lake monzogabbro, the intrusive rocks localized deformation. Most amphibolites experienced a renewed episode of deformation to form the amphibolite-diorite-tonalite tectonites that are abundant along the SESZ and NWSZ. Where the diorites and tonalites intruded directly into gabbros, they were highly deformed while the gabbros underwent mainly static contact metamorphism. This is indicated by the large deformation contrast between the highly strained diorites and the undeformed, contact metamorphosed host gabbros, as well as the microstructures indicative of magmatic deformation. The greenschist grade of the contact metamorphism and preservation of high temperatures in the diorites $\left(\sim 750^{\circ} \mathrm{C}\right)$ suggests the regional ambient temperature of the Lloyds River Fault Zone during intrusion was relatively low. Locally, deformation in the Pierre's Pond suite continued at greenschist-facies conditions, indicated by growth of epidote+chlorite along cleavage planes.

[30] In summary, the Lloyds River Fault Zone thus records the high-temperature sinistral oblique accretion of the Annieopsquotch ophiolite belt to the composite Laurentian margin, and subsequent periodic high-temperature reactivation triggered by the intrusion of plutons. Reactivation occurred along the majority of the Lloyds River Fault Zone within the study area, and led to the formation of most of the Lloyds River Fault Zone mylonites. Intrusion of the plutons locally caused an increase in the geothermal gradient, but on a regional-scale temperatures were already significantly lower $\left(<550^{\circ} \mathrm{C}\right)$ than the $\sim 800^{\circ} \mathrm{C}$ accompanying the initial accretionary event prior to circa $471 \mathrm{Ma}$.

\subsection{Heat Source During Initial Accretion}

[31] Rocks in accretionary complexes are generally subject to high-P, low-T metamorphism since isotherms are depressed by subduction of cool lithosphere. Whereas the Annieopsquotch ophiolite belt occurs in an accretionary setting, and marks the subduction of infant arc lithosphere, it was metamorphosed at high $\mathrm{T}\left(\sim 800^{\circ} \mathrm{C}\right)$ and at moderate 
pressures ( $\sim 6 \mathrm{kbar}$ ) during its initial accretion. A likely explanation for these elevated temperatures lies in the fact that the Dashwoods microcontinent was basement to the Notre Dame Arc after 488 Ma [Dubé et al., 1996], and hence was characterized by a high geothermal gradient when it was thrust over the Annieopsquotch ophiolite belt. The inverted geothermal gradient beneath the overriding microcontinent led to high-temperature metamorphism along the Lloyds River Fault Zone, which, prior to the intrusion of the Portage Lake monzogabbro and Pierre's Pond suite, was likely significantly narrower than its current width. The temperature gradient underneath the thrust was likely sharp and the thermal pulse short-lived, which may explain the preservation of seafloor-spreading-related features within the interior of the Annieopsquotch ophiolite [Dunning, 1987; Lissenberg et al., 2004] and the preserved prograde zoning in some amphibolites. This scenario is consistent with relationships along the Hungry Mountain thrust, which forms part of Lloyds River Fault Zone-related faults farther to the north, and accommodated overthrusting of the Annieopsquotch Accretionary Tract by a hot sheet comprising plutonic rocks of the Hungry Mountain Complex [Thurlow, 1981]. Thrusting led to an inverted metamorphic gradient with amphibolite-facies metamorphism immediately beneath the thrust to (sub)greenschist-facies metamorphism at structurally deeper levels [Thurlow, 1981]. Hence thrusting must have occurred shortly after crystallization of the Hungry Mountain Complex (467 \pm $8 \mathrm{Ma}$ [Whalen et al., 1987]), consistent with the age constraints on thrusting along the Lloyds River Fault Zone.

\subsection{Feedback Between Deformation and Magmatism}

[32] Whereas many amphibolites were metamorphosed and deformed synchronously with intrusion of the $459 \pm$ 3 Ma Pierre's Pond suite, as is evidenced by the amphibolitediorite-tonalite tectonites that mark segments of the NWSZ and SESZ (Figures 3, 7, 10, and 11b), several arguments presented below suggest that the Lloyds River Fault Zone was already active prior to intrusion of the Portage Lake monzogabbro and Pierre's Pond suite.

[33] 1. The cooling age of the amphibolite bounding the Star Lake ophiolite (471 $\pm 5 \mathrm{Ma})$ and the crystallization ages of the Portage Lake monzogabbro (464 \pm 2 and $462 \pm$ $2 \mathrm{Ma})$ and Pierre's Pond suite $(459 \pm 3 \mathrm{Ma})$ can be distinguished at the $2 \sigma$ level [Lissenberg et al., 2005a]. Whereas the cooling age of the amphibolite bounding the Annieopsquotch ophiolite (468 $\pm 6 \mathrm{Ma})$ overlaps with the age of the Portage Lake monzogabbro, the probability of overlap is very low (0.001). This suggest that this amphibolite preserves the age of initial underthrusting, rather than a thermal pulse associated with the intrusion of the plutons.

[34] 2. The Pierre's Pond suite and the $468 \pm 2$ Ma Otter Pond suite, which both intrude the Annieopsquotch ophiolite, have geochemical and isotopic signatures, as well as inherited zircon, that require a component of crustal assimilation in their petrogenesis [Lissenberg et al., 2005a]. Hence the Annieopsquotch ophiolite belt was already accreted to the Dashwoods microcontinent prior to this magmatism.
[35] 3. The Portage Lake monzogabbro has a high aspect ratio parallel to the Lloyds River Fault Zone, consistent with intrusion along a preexisting structural anisotropy.

[36] Hence we conclude that the Lloyds River Fault Zone was already active prior to intrusion of the Portage Lake monzogabbro and Pierre's Pond suite and served as a guide for the ascending magmas. However, the presence of melt sparked renewed high-temperature deformation, recorded in the magmatic fabrics of both plutonic suites, and caused thermal softening of the fault zone, leading to high-temperature solid-state deformation. This deformation was localized mostly within the plutonic rocks themselves and the immediately adjacent amphibolites; the preservation of the older Ar/Ar ages indicate that amphibolites further removed from the plutons were not influenced by this episode. Continued solid-state deformation within the plutons but not in the amphibolites, is consistent with the rheologically weaker nature of the hot quartz-biotite bearing plutons relative to the already cooled amphibolites [cf. Pavlis, 1996].

[37] In the Lloyds River Fault Zone, establishment of the shear zone thus preceded magmatism, but a positive feedback occurred between deformation and magmatism. Similar relationships have been documented elsewhere [e.g., Davidson et al., 1992; Vauchez et al., 1997; De Saint Blanquat et al., 1998; Moyen et al., 2003]. In the periphery of the Lloyds River Fault Zone, however, magmatism appears to have triggered formation of new shear zones; the small-scale diorite-tonalite offshoots of the Pierre's Pond suite sheets around Star Lake are highly deformed at amphibolite-facies conditions, while their host gabbros remain undeformed and are subject to greenschist-grade contact metamorphism, suggesting deformation nucleated within the intrusive rocks. Thus while the main pluton intruded into a shear zone, its offshoots intruded outside the shear zone and initiated the formation of new small-scale shear zones. Deformation, magmatism and metamorphism were thus intimately related, and, whereas deformation generally preceded intrusion, locally magmatism preceded deformation. Both end-members may thus operate simultaneously within a single fault system.

[38] There has been debate as to whether shear zones provide space for pluton emplacement [e.g., Hutton, 1988; Karlstrom, 1989; Paterson, 1989; Tikoff and Teyssier, 1992]. In the Lloyds River Fault Zone, there is a positive correlation between the presence of plutons and shear zone width; the fault zone is wide in its center, where the Portage Lake monzogabbro and Pierre's Pond suite are most abundant, but is considerably narrower to the northeast and southwest, where the Portage Lake monzogabbro is absent and Pierre's Pond suite less abundant (Figure 1). Although it could be argued that the along-strike thinning of the Pierre's Pond suite is in part due to translation, the absence of the Portage Lake monzogabbro in the narrower segments suggests at least part of the observed variability is a primary feature. The Pierre's Pond suite contains several map-scale blocks of ophiolitic gabbros, suggesting emplacement at least in part occurred by stopping. However, it is striking that the plutons are thickest in the segment where the 
generally northeast striking Lloyds River Fault Zone curves to the south (Figure 1), which may suggest they were preferentially emplaced in a dilational jog created during sinistral oblique movement [cf. Hutton, 1988]. Whereas we do not have enough data to reconstruct in detail the relative importance of stopping, floor subsidence and roof uplift, the Lloyds River Fault Zone thus may have played an active role in creating space for pluton emplacement.

\section{Conclusion}

[39] The Lloyds River Fault Zone comprises amphibolites that accommodated sinistral-oblique underthrusting of the ophiolites beneath the composite Laurentian margin, and played an important role in the transfer of intraoceanic complexes to the Laurentian continent. The Lloyds River Fault Zone comprises three shear zones marked by amphibolites, and two suites of plutonic rocks. The amphibolites formed during initial accretion $(>471 \pm 5 \mathrm{Ma})$ of the ophiolites at high temperatures $\left(\sim 800^{\circ} \mathrm{C}\right)$ and pressures of $\sim 6$ kbar. The Lloyds River Fault Zone was intruded synkinematically by two plutonic suites at $464 \pm 2$ to $462 \pm 2 \mathrm{Ma}$ and $459 \pm 3 \mathrm{Ma}$. Intrusion localized deformation in the plutonic rocks, initially in the magmatic state but also at high temperatures in the solid-state during cooling $\left(\sim 770-750^{\circ} \mathrm{C}\right)$. The current configuration of the Lloyds River Fault Zone thus results from a positive feedback between deformation and magmatism. However, offshoots of the plutons that intruded unfoliated gabbro outside the Lloyds River Fault Zone initiated formation of small-scale shear zones. This illustrates that channeling of plutons into shear zones and nucleation of shear zones in melt-rich zones may occur simultaneously within the same fault system. Since accretionary complexes are commonly intruded by plutons as a result of hinge retreat, this type of structural evolution may characterize many accretionary margins, indicating that plutons may play a significant role in the transfer of oceanic material to continents.

[40] Acknowledgments. This research is funded by a scholarship from the Faculty of Graduate and Postdoctoral Studies, University of Ottawa, to C.J.L. and a NSERC grant to C.v.S in his position as Adjunct Professor at the University of Ottawa. We would like to thank Alexandre Zagorevski, Joe Whalen, Sally Pehrsson, Arjan Brem, Neil Rogers, and Jean Bédard for discussions of Newfoundland geology; David Portsmouth and Max McGillen for able field assistance; and especially Vicki McNicoll for her involvement in the geochronological aspects of this study. Constructive reviews by Keith Benn, Rob Berman, Simon Hanmer, and an anonymous reviewer significantly improved the manuscript. Katherine Venance is acknowledged for performing microprobe analyses, and Rob Berman is acknowledged for advice on geothermobarometry. This is GSC contribution 2004276.

\section{References}

Armstrong, J. T. (1988), Quantitative analysis of silicates and oxide minerals: Comparison of MonteCarlo, ZAF and Phi-Rho-Z procedures, in Microbeam Analysis, edited by D. E. Newbury, pp. 239246, San Francisco Press, San Francisco, Calif.

Berman, R. G. (1988), Internally-consistent thermodynamic data for stoichiometric minerals in the system $\mathrm{Na}_{2} \mathrm{O}-\mathrm{K}_{2} \mathrm{O}-\mathrm{CaO}-\mathrm{MgO}-\mathrm{FeO}-\mathrm{Fe}_{2} \mathrm{O}_{3}-\mathrm{Al}_{2} \mathrm{O}_{3}$ $\mathrm{SiO}_{2}-\mathrm{TiO}_{2}-\mathrm{H}_{2} \mathrm{O}-\mathrm{CO}_{2}$, J. Petrol., 29, 445-522.

Berman, R. G. (1991), Thermobarometry using multiequilibrium calculations: A new technique with petrologic applications, Can. Mineral., 29, $833-$ 855.

Brem, A. G., S. Lin, and C. R. van Staal (2003), Structural relationships south of Grand Lake, Newfoundland, Current Research, Rep. 03-1, pp. 113, Newfoundland Dep. of Mines and Energy, Geol. Surv., St. Johns.

Brown, M., and G. S. Solar (1998), Shear-zone systems and melts: Feedback relations and self-organization in orogenic belts, J. Struct. Geol., 20 , $211-227$.

Calon, T. J., and F. K. Green (1987), Preliminary results of a detailed structural analysis of the $\mathrm{Bu}$ chans Mine area, in Buchans Geology, Newfoundland, edited by R. V. Kirkham, Geol. Surv. Can. Pap., 86-24, 273-288.

Cawood, P. A., P. J. A. McCausland, and G. R. Dunning (2001), Opening Iapetus; constraints from the Laurentian margin in Newfoundland, Geol. Soc. Am. Bull., 113, 443-453.

Chemenda, A. I., R.-K. Yang, J.-F. Stephan, E. A. Konstantinovskaya, and G. M. Ivanov (2001) New results from physical modelling of arc-continent collision in Taiwan: Evolutionary model, $\mathrm{Tec}-$ tonophysics, 333, 159-178.

Davidson, C., L. S. Hollister, and S. M. Schmid (1992), Role of melt in the formation of a deepcrustal compressive shear zone: The Maclaren Glacier metamorphic belt, south central Alaska, Tectonics, $11,348-359$.
Dean, P. L., and D. F. Strong (1977), Folded faults in Notre Dame bay, central Newfoundland, Am. J. Sci., 277, 97-108.

De Saint Blanquat, M., B. Tikoff, C. Teyssier, and J. L. Vigneresse (1998), Transpressional kinematics and magmatic arcs, in Continental Transpressional and Transtensional Tectonics, edited by R. E. Holdsworth, R. A. Stachan, and J. F. Dewey, Geol. Soc. Spec. Publ., 135, 327-340.

Dubé, B., G. R. Dunning, K. Lauziere, and J. C. Roddick (1996), New insights into the Appalachian orogen from geology and geochronology along the Cape Ray fault zone, southwest Newfoundland, Geol. Soc. Am. Bull., 108, $101-116$.

Dunning, G. R. (1987), Geology of the Annieopsquotch Complex, southwest Newfoundland, Can. J. Earth Sci., 24, 1162-1174.

Dunning, G. R., and T. E. Krogh (1985), Geochronology of ophiolites in the Newfoundland Appalachians, Can. J. Earth Sci., 22, 1659-1670.

Dunning, G. R., D. H. C. Wilton, and R. K. Herd (1989), Geology, geochemistry and geochronology of a Taconic batholith, southwestern Newfoundland, Trans. R. Soc. Edinburgh, 80, $159-168$.

Fuhrman, M. L., and D. H. Lindsley (1988), Ternaryfeldspar modeling and thermometry, Am. Mineral., $73,201-216$.

Holland, T., and J. Blundy (1994), Non-ideal interactions in calcic amphiboles and their bearing on amphibole-plagioclase thermometry, Contrib. Mineral. Petrol., 116, 433-447.

Hollister, L. S., and M. L. Crawford (1986), Melt-enhanced deformation: A major tectonic process, Geology, 14, 558-561.

Hutton, D. H. W. (1988), Granite emplacement mechanisms and tectonic controls: Inferences from deformation studies, Trans. R. Soc. Edinburgh, $79,245-255$.

Karlstrom, K. E. (1989), Toward a syntectonic paradigm for granitoids, Eos Trans. AGU, 70, 762.
Leake, B. E., et al. (1997), Nomenclature of the amphiboles: Report of the Subcommittee on Amphiboles of the International Mineralogical Association, Commission on New Minerals and Mineral Names, Can. Mineral., 35, $219-$ 246.

Lin, S., D. Jiang, and P. F. Williams (1998), Transpression (or transtension) zones of triclinic symmetry: Natural example and theoretical modeling, in Continental Transpressional and Transtensional Tectonics, edited by R. E. Holdsworth, R. A. Stachan, and J. F. Dewey, Geol. Soc. Spec. Publ., $135,41-57$.

Lissenberg, C. J., and C. R. van Staal (2002), The relationships between the Annieopsquotch Ophiolite Belt, the Dashwoods Block and the Notre Dame Arc in Southwestern Newfoundland, Current Research, Rep. 02-1, pp. 145-153, Newfoundland Dep. of Mines and Energy, Geol. Surv., St. Johns.

Lissenberg, C. J., J. H. Bédard, and C. R. van Staal (2004), The structure and geochemistry of the gabbro zone of the Annieopsquotch ophiolite, Newfoundland: Implications for lower crustal accretion at spreading ridges, Earth Planet. Sci. Lett., 229, 105-123.

Lissenberg, C. J., A. Zagorevski, V. J. McNicoll, C. R. van Staal, and J. B. Whalen (2005a), Assembly of the Annieopsquotch Accretionary Tract, Newfoundland Appalachians: Age- and geodynamic constraints from syn-kinematic intrusions, J. Geol., $113,553-570$

Lissenberg, C. J., C. R. van Staal, J. H. Bédard, and A. Zagorevski (2005b), Geochemical constraints on the origin of the Annieopsquotch ophiolite belt, southwest Newfoundland, Geol. Soc. Am. Bull., 117, 1413-1426.

Lissenberg, C. J., A. Zagorevski, J. B. Whalen, and C. R. van Staal (2005c), Geology, Star Lake, Newfoundland (NTS 12A/11), scale 1:50,000, Open File 1669, Geol. Surv. of Can., Ottawa, Ont. 
Mader, U. K., and R. G. Berman (1992), Amphibole thermobarometry: A thermodynamic approach, Current Research, Geol. Surv. Can. Pap., 92-1E, $393-400$.

McCaffrey, K. J. W. (1992), Igneous emplacement in a transpressive shear zone: Ox Mountains igneous complex, J. Geol. Soc. London, 149, $221-235$.

Moyen, J.-F., A. Nédélec, H. Martin, and M. Jayananda (2003), Syntectonic granite emplacement at different structural levels: The Closepet granite, south India, J. Struct. Geol., 25, 611-631.

Paterson, S. R. (1989), Are syntectonic granites truly syn-tectonic?, Eos Trans. AGU, 70, 763.

Pavlis, T. L. (1996), Fabric development in syn-tectonic intrusive sheets as a consequence of meltdominated flow and thermal softening of the crust, Tectonophysics, 253, 1-31.

Rosenberg, C. L. (2004), Shear zones and magma ascent: A model based on a review of the Tertiary magmatism in the Alps, Tectonics, 23, TC3002, doi:10.1029/2003TC001526

Spear, F. S. (1981), An experimental study of hornblende stability and compositional variability in amphibolite, Am. J. Sci., 281, 697-734.

Swinden, H. S., G. A. Jenner, and Z. A. Szybinski (1997), Magmatic and tectonic evolution of the Cambrian-Ordovician Laurentian margin of Iapetus: Geochemical and isotopic constraints from the Notre Dame subzone, Newfoundland, in The Nature of Magmatism in the Appalachian Orogen, edited by A. K. Sinha, J. B. Whalen, and J. P. Hogan, Mem. Geol. Soc. Am., 191, 337-365.

Thurlow, J. G. (1981), The Buchans group: Its stratigraphic and structural setting, in The Buchans Orebodies: Fifty Years of Geology and Mining, edited by E. A. Swanson, D. F. Strong, and J. G. Thurlow, Geol. Assoc. Can. Spec. Pap., 22, 79-90.

Thurlow, J. G., C. P. Spencer, D. E. Boerner, L. E. Reed, and J. A. Wright (1992), Geological interpretation of a high resolution reflection seismic survey at the Buchans mine, Newfoundland, Can. J. Earth Sci., 29, 2022-2037.

Tikoff, B., and C. Teyssier (1992), Crustal-scale, enechelon "P-shear" tensional bridges: A possible solution to the batholithic room problem, Geology, 20, 927-930.

Urai, J. L., W. D. Means, and G. S. Lister (1986), Dynamic recrystallization of minerals, in Mineral and Rock Deformation: Laboratory Studies (the
Paterson Volume), Geophys. Monogr. Ser, vol. 36, edited by B. E. Hobbs and H. C. Heard, pp. 161-199, AGU, Washington, D. C.

van der Velden, A. J., C. R. van Staal, and F. A. Cook (2004), Paleosubduction of Ganderia beneath Laurentia: A reprocessed Lithoprobe seismic reflection survey of the Newfoundland Appalachians, Geol. Soc. Am. Bull., 116, 1485-1498.

van Staal, C. R., J. F. Dewey, C. Mac Niocaill, and W. S. McKerrow (1998), The Cambrian-Silurian tectonic evolution of the northern Appalachians and British Caledonides: History of a complex, west and southwest Pacific type segment of Iapetus, in Lyell: The Past is the Key to the Present, edited by D. J. Blundell and A. C. Scott, Geol. Soc. Spec. Publ, 143, 199-242.

van Staal, C. R., J. B. Whalen, S. J. Pehrsson, and V. J. McNicoll (2003), Tectonic evolution of the Notre Dame magmatic arc, Newfoundland Appalachians, Eos Trans. AGU, 84(46), Fall Meet. Suppl., Abstract V41A-06

van Staal, C. R., C. J. Lissenberg, S. Pehrsson, A. Zagorevski, P. Valverde-Vaquero, R. K. Herd, V. McNicoll, and J. Whalen (2005a), Geology, Puddle Pond, Newfoundland (NTS 12A/05) scale 1:50,000, Open File 1664, Geol. Surv. of Can., Ottawa, Ont

van Staal, C. R., A. Zagorevski, P. Valverde-Vaquero, N. Rogers, and C. J. Lissenberg (2005b), Geology, Victoria Lake, Newfoundland (NTS 12A/06), scale 1:50,000, Open File 1667, Geol. Surv. of Can. Ottawa, Ont.

van Staal, C. R., P. Valverde-Vaquero, A. Zagorevski, S. Boutsma, S. Pehrsson, M. van Noorden, and V. McNicoll (2005c), Geology, King George IV Lake, Newfoundland (NTS 12A/04), scale 1:50,000, Open File 1665, Geol. Surv. of Can. Ottawa, Ont.

Vauchez, A., S. Pacheco Neves, and A. Tommas (1997), Transcurrent shear zones and magma emplacement in Neoproterozoic belts of Brazil, in Granite: From Segregation of Melt to Emplace ment Fabrics, edited by J. L. Bouchez et al., pp. 275-293, Springer, New York.

Vernon, R. H. (2000), Review of microstructural evi dence of magmatic and solid-state flow, Electron Geosci., 5, 2.

Waldron, J. W. F., and C. R. van Staal (2001), Taconian orogeny and the accretion of the Dashwoods block:
A peri-Laurentian microcontinent in the Iapetus ocean, Geology, 29, 811-814.

Whalen, J. B., K. L. Currie, and O. van Breemen (1987), Episodic Ordovician-Silurian plutonism in the Topsails igneous terrane, western Newfoundland, Trans. R. Soc. Edinburgh, 78, 17-28.

Whalen, J. B., G. A. Jenner, F. J. Longstaffe, C. Gariepy, and B. J. Fryer (1997), Implications of granitoid geochemical and isotopic $(\mathrm{Nd}, \mathrm{O}, \mathrm{Pb})$ data from the Cambrian-Ordovician Notre Dame arc for the evolution of the Central Mobile belt, Newfoundland Appalachians, The Nature of Magmatism in the Appalachian Orogen, edited by A. K. Sinha, J. B. Whalen, and J. P. Hogan, Mem.Geol. Soc. Am., 191, 367-395.

Whalen, J. B., V. J. McNicoll, C. R. van Staal, C. J. Lissenberg, F. J. Longstaffe, G. A. Jenner, and O. van Breeman (2006), Spatial, temporal and geochemical characteristics of Silurian collision-zone magmatism, Newfoundland Appalachians: An example of a rapidly evolving magmatic system related to slab break-off, Lithos, doi:10.1016/ j.lithos.2005.12.011, in press.

Williams, H. (1979), Appalachian orogen in Canada Can. J. Earth Sci., 16, 792-807.

Williams, H., S. P. Colman-Sadd, and H. S. Swinden (1988), Tectonic-stratigraphic subdivision of central Newfoundland, Current Research, Geol. Surv. Can. Pap., 88-1B, $91-98$

Zagorevski, A., and C. R. van Staal (2002), Structures associated with the Red Indian Line in southwestern Newfoundland, Current Research, Rep. 02-I, pp. 211-218, Newfoundland Dep. of Mines and Energy, Geol. Surv., St. Johns.

Zagorevski, A., N. Rogers, C. R. van Staal, V. McNicoll, C. J. Lissenberg, and P. Valverde-Vaquero (2006), Lower to Middle Ordovician evolution of periLaurentian arc and back-arc complexes in Iapetus: Constraints from the Annieopsquotch Accretionary Tract, central Newfoundland, Geol. Soc. Am. Bull., 118, 324-342.

C. J. Lissenberg, Woods Hole Oceanographic Institution, 360 Woods Hole Road, MS 8, Woods Hole, MA 02543, USA. (jlissenberg@whoi.edu)

C. R. van Staal, Geological Survey of Canada, Natural Resources Canada, 615 Booth Street, Ottawa, ON, Canada K1A 0E8. (cvanstaa@nrcan.gc.ca) 